\title{
1. Human rights in development cooperation
}

\subsection{A CASE STUDY ON ETHIOPIA'S PROTECTION OF BASIC SERVICES (PBS) PROGRAMME}

Ethiopia hosts a population of an estimated 101,853 million people, composed of various ethnic and religious groups. ${ }^{1}$ Its economy is largely based on agriculture, services and industry; its natural resources include potash, gold, copper, platinum, salt and natural gas. ${ }^{2}$ Ethiopia has continuously strived towards industrialising agriculture, increasing exports and attracting foreign direct investment. These efforts have brought about quick economic growth which has however not resulted in corresponding improvements in the livelihoods for the people. Ethiopia therefore remains one of the poorest countries and one of the largest recipients of aid in the world. ${ }^{3}$

From a development perspective Ethiopia has nevertheless been hailed as a success story. The development community has praised Ethiopia with respect to two particular aspects of development. ${ }^{4}$ The first is

1 UN Data, country profile Ethiopia (2017), <http://data.un.org/Country Profile.aspx?crName=ethiopia $>$, accessed 4 Jan 2017.

2 African Development Bank Group, Ethiopia. Economic Outlook (2018), $<$ https://www.afdb.org/en/countries/east-africa/ethiopia/ethiopia-economic-out look/>, accessed Jul 2018; Worldatlas, What are the major natural resources of Ethiopia? <https://www.worldatlas.com/articles/what-are-the-major-naturalresources-of-ethiopia.html>, accessed 15 Jul 2018.

3 Human Rights Watch, Ethiopia: Development without Freedom: How Aid Underwrites Repression in Ethiopia, (13.10.2010), <http://www.hrw.org/sites/ default/files/reports/ethiopia1010webwcover.pdf>, accessed 4 Jul 2018 12; OECD, Development Aid at a Glance, <http://www.oecd.org/dac/financingsustainable-development/development-finance-data/World-Development-Aid-ata-Glance-2018.pdf>, accessed 15 Jul 2018, 2.

4 International Crisis Group, Ethiopia After Meles: Africa Briefing no ${ }^{\circ} 89$, (22.08.2012), <https://www.crisisgroup.org/africa/horn-africa/ethiopia/ethiopiaafter-meles>, accessed 5 Jul 2018, 5-12; African Development Bank Group, Ethiopia. Economic Outlook (2018). 
Ethiopia's rapid economic progress and its exemplary improvement on quantitative development indicators. ${ }^{5}$ According to the United Nations Development Assistance Framework, Ethiopia's Human Development Index improved by an annual average growth rate of 3.2 per cent between 2000 and 2014. This was the third fastest growth rate in the world since 2000.6 The growth rate has continued throughout the last years. The UN Development Assistance Framework for Ethiopia underlines that Ethiopia has 'sustained double-digit growth over the past twelve years' which is almost double the Sub-Saharan average growth rate. ${ }^{7}$ The second aspect which has been brought forward by the development community is Ethiopia's political commitment to federalism and democracy as well as its cooperation with the international community. Furthermore Ethiopia has proved itself to be a trusted and reliable ally in the fight against terrorism in the Horn of Africa which constitutes an important security issue. Despite these strategic aspects playing an important role in international relations, the international development community has often been criticised for prioritising them and turning a blind eye to Ethiopia's deplorable human rights situation. ${ }^{8}$

The human rights perspective on Ethiopia differs substantially from the development perspective. From a legal perspective Ethiopia has ratified almost all international human rights treaties including the International Covenant on Civil and Political Rights (ICCPR), the International Covenant on Economic, Social and Cultural Rights (ICESCR), the Convention against Torture (CAT), the Convention on the Elimination of Discrimination against Women (CEDAW), the Convention on the Elimination of All Forms of Racial Discrimination (CERD), the Convention on the Rights of the Child (CRC) and the Convention on the Rights of People with Disabilities (CRPD). ${ }^{9}$ Ethiopia's constitution is based on the principle of

5 Human Rights Watch, Ethiopia: Development without Freedom: How Aid Underwrites Repression in Ethiopia, (13.10.2010), 5-12.

6 United Nations Country Team, Ethiopia: United Nations Development Assistance Framework 2016 to 2020, <https://www.undp.org/content/dam/unct/ ethiopia/docs/Final\%20UNDAF\%202016-2020\%20for\%20web.pdf>, accessed 15 Jul 2018, 3.

7 Ibid, 7.

8 International Crisis Group, Ethiopia After Meles: Africa Briefing no ${ }^{\circ} 89$, (22.08.2012), 5-12.

9 Office of the United Nations High Commissioner for Human Rights (OHCHR), Status of Ratification of Human Rights Instruments, <www.ohchr.org/ Documents/HRBodies/HRChart.xls> accessed 2 Nov 2016. 
rule of law and the respect for human rights. ${ }^{10}$ Ethiopia also established a Human Rights Commission and a national Ombudsman. ${ }^{11}$ The factual situation is however completely different and human rights are far from being realised on the ground. ${ }^{12}$

The Ethiopian Peoples' Revolutionary Democratic Front (EPRDF), a coalition which came to power in the early 1990s, at the end of the civil war, dominated the political scene for 25 years. ${ }^{13}$ Until his death in August 2012, Prime Minister Meles Zenawi constituted a personalised centre of power. ${ }^{14}$ Despite the formal commitment to a democratic system, he ruled the country with an authoritarian one-party system building an extensive apparatus of control and repression. ${ }^{15}$ This apparatus has equally posed key problems for the implementation of the Protection of Basic Services (PBS) programme. Its repressive structures became particularly evident in the course of Ethiopia's 2005 elections, when the opposition for the first time challenged the ruling party and gained considerable support. EPRDF remained in power but the results were contested for manipulation and answered by violent protests which ultimately led to the killing of almost 200 and the arrest of 20,000 people. ${ }^{16}$ Since 2005 the EPRDF has passed a range of restrictive laws in

10 Constitutional Assembly, Constitution of the Federal Democratic Republic of Ethiopia, (08/12/1994), <http://unpan1.un.org/intradoc/groups/public/ documents/un-dpadm/unpan040910.pdf>, accessed 29 Nov 2017, preamble, art 10; Kassie Abebe, 'Human Rights under the Ethiopian Constitution: A Descriptive Overview' (22.07.2011), Mizan Law Review 5/1 (2011) <http://www. ajol.info/index.php/mlr/article/viewFile/68768/56833>, accessed 29 Nov 2017, 43, 44.

11 Ethiopian Human Rights Commission, Profile and History, (30.11.2012) $<$ http://www.ehrc.org.et/>, updated 30 Nov 2016.

12 Austrian Development Agency (ADA), Äthiopien Länderinformation, (01.05.2018), <https://www.entwicklung.at/fileadmin/user_upload/Dokumente/ Laenderinformationen/LI_Aethiopien_Mai2018.pdf>, accessed 15 Jul 2018, 4.

13 Ibid.; House of Peoples' Representatives and State Council Elections, Election Observation Mission - Ethiopia 2010 High Turnout on a Peaceful and Orderly Election Day Marred by a Narrowing of Political Space and an Uneven Playing Field, (25.05.2010), <http://eeas.europa.eu/eueom/pdf/missions/eu-eomethiopia-preliminary-statement-25052010_en.pdf>, accessed 15 Nov 2017.

14 International Crisis Group, Ethiopia After Meles: Africa Briefing no ${ }^{\circ} 89$, (22.08.2012), 1.

15 Human Rights Watch, Ethiopia: Development without Freedom: How Aid Underwrites Repression in Ethiopia, (13.10.2010), 10.

16 International Crisis Group, Ethiopia After Meles: Africa Briefing no ${ }^{\circ} 89$, (22.08.2012), 4-5; House of Peoples' Representatives and State Council Elections, Election Observation Mission - Ethiopia 2010: High Turnout on a 
the name of national security and terror prevention, such as the Mass Media and Freedom of Information Proclamation or the Anti-Terrorism Proclamation which allows the issuing of penalties and arrests to silence critical voices. Since 2009, the Charities and Societies Proclamation has imposed strict controls, fines and arrests of human rights defenders and local NGOs. ${ }^{17}$

Surrounded by restrictions, Ethiopia's 2010 elections saw limitations of freedom of expression, association and assembly as well as intimidation and harassment of opposition members. Violence was also directed against civilians, who were threatened with losing access to education opportunities, civil service jobs or even food assistance if they refused to vote for or join the ruling party. Not very surprisingly EPRDF again gained 90 per cent of the vote. ${ }^{18}$ This climate continued during the 2015 elections which reconfirmed the ruling party by a landslide victory. ${ }^{19}$ According to Human Rights Watch there was hardly any opportunity for a meaningful political debate allowing for critical voices and dissenting opinions to be heard. Opposition parties and independent journalists reported harassment and political prosecution as well as challenging hurdles to holding rallies or to registering opposition candidates. Independent media had been systematically repressed by closing publishing houses and press offices and by issuing criminal charges against journalists and writers. The Charities and Societies Proclamation bars NGOs from work on human rights, conflict resolution and advocacy if they receive more than 10 per cent of their budget from foreign entities. ${ }^{20}$

Peaceful and Orderly Election Day Marred by a Narrowing of Political Space and an Uneven Playing Field, (25.05.2010).

17 Amnesty International, Ethiopia: Annual Report 2011, (2012) <https:// www.amnestyusa.org/reports/annual-report-ethiopia-2011/>, accessed 29 Nov 2017.

18 House of Peoples' Representatives and State Council Elections, Election Observation Mission Ethiopia 2010: High Turnout on a Peaceful and Orderly Election Day Marred by a Narrowing of Political Space and an Uneven Playing Field (05.05.2010), 2; Amnesty International, ibid.

19 Daniel Calingaert and Kellen McClure, Ethiopia's election is a wake-up call on human rights and sound governance, (23.05.2015), <http://www.the guardian.com/global-development/2015/may/23/ethiopia-election-wake-up-callhuman-rights-governance>, accessed 13 Jul 2018; BBC, Ethiopia election: EPRDF wins every seat in parliament, (22.06.2015), <http://www.bbc.com/ news/world-africa-33228207>, accessed 13 Aug 2015; Human Rights Watch, World Report 2016: Ethiopia, <https://www.hrw.org/world-report/2016/countrychapters/ethiopia> accessed 27 Jan 2017.

20 Human Rights Watch, World Report 2016: Ethiopia. 
The year 2016 was characterised by unprecedented protests in the Oromia and the Amhara regions against Ethiopia's repressive regime. Hundreds of people were killed and thousands of teachers, students, health workers, opposition party members, and civilians who sheltered protesters were arrested and charged under the Anti-Terrorism Proclamation. The government declared a state of emergency which widely suspended the provisions on freedom of expression, assembly and association and gave far reaching powers to the security forces. ${ }^{21}$

Already in May 2012, two human rights monitoring bodies had highlighted the country's alarming human rights situation: The African Commission on Human and Peoples' Rights called on Ethiopia to allow independent monitoring of places of detention, to provide medical treatment, to ensure access to legal counselling and a fair trial, to close all unofficial places of detention, to train the judiciary, to ensure protection of human rights defenders and to remove restrictions on freedom of expression. ${ }^{22}$ The UN Committee on Economic, Social and Cultural Rights urged Ethiopia to ensure that its Human Rights Commission was in line with the Paris Principles and to lift restrictions set on NGOs. ${ }^{23}$ Furthermore it required Ethiopia to adopt a comprehensive anti-discrimination bill, to reduce unemployment, to comply with international labour standards, to combat child labour and child trafficking, and to ensure free and compulsory primary education. It equally called upon Ethiopia to enforce criminal provisions on female genital mutilation and domestic violence, to ensure access to adequate housing and to avoid forced evictions, to address chronic food insecurity and to improve access to health care, water and sanitation. Finally, the Committee required Ethiopia to address the social and environmental impact of the Gibe III Hydropower dam implemented in the Omo river valley and to conduct extensive consultations with affected groups. ${ }^{24}$

21 Human Rights Watch, World Report 2017: Ethiopia, <https://www.hrw. org/world-report/2017/country-chapters/ethiopia> accessed 27 Jan 2017.

22 African Commission on Human and Peoples Rights, Resolution on the Human Rights Situation in the Democratic Republic of Ethiopia No. 218, (02.05.2012), <http://www.achpr.org/sessions/51st/resolutions/218/>, accessed 29 Nov 2017.

23 UN General Assembly, Principles relating to the Status of National Institutions (The Paris Principles), resolution 48/134 (20.12.1993) <https://www. un.org/ruleoflaw/files/PRINCI 5.PDF>, accessed 28 Mar 2019.

24 Committee on Economic Social and Cultural Rights, Consideration of reports submitted by States parties under articles 16 and 17 of the Covenant: Concluding observations of the Committee on Economic Social and Cultural 
Gibe III has been subject to debates similar to those on the Ilisu Hydropower Dam Project in Turkey. Realised within the framework of Ethiopia's economic development plan, Gibe III has been under construction since 2006 and will be the biggest dam in Africa. It has been implemented by the Ethiopian Electric Power Corporation (EEPCO) and co-funded by the Ethiopian government, the World Bank and the Chinese and Italian governments. ${ }^{25}$ The African Development Bank and the European Investment Bank withdrew their support after evaluating the project. ${ }^{26}$ Gibe III has been harshly criticised for a broad range of human rights violations, in particular, harassment, violence and arbitrary arrests, the lack of adequate consultation and forced evictions of indigenous groups from their ancestral lands. ${ }^{27}$ In 2015 the dam began to be filled. Since then violent clashes between the government and ethnic groups as well as among ethnic groups have increased due to increased competition for resources and grazing land. Contrary to government promises there was no artificial flooding after the filling which is important for watering the agricultural lands along the river. ${ }^{28}$

Furthermore, Ethiopia's 'villagisation' programme which aimed at resettling 1.5 million families including indigenous communities to new villages resulted in large-scale forced evictions. ${ }^{29}$ Relocations took place without any meaningful consultation or compensation and were accompanied with intimidation and arbitrary arrests. Human Rights Watch reported that many new villages were lacking basic services, food, infrastructure and agricultural support. Interestingly, 'villagisation' was undertaken in particular in areas which have been leased to domestic or foreign investors. ${ }^{30}$

Rights: Ethiopia E/C.12/ETH/CO/1-3, (31.05.2012), <https://www.ohchr.org/en/ hrbodies/cescr/pages/cescrindex.aspx>, accessed 2 Dec 2017, paras 5-31.

25 Gibe III Hydroelectric Project, Gibe III Hydroelectric Project, <http:// www.gibe3.com.et/>, accessed 2 Dec 2017.

26 Survival International, The Omo Valley Tribes, <http://www.survival international.org/tribes/omovalley/gibedam>, accessed 3 May 2018.

27 Human Rights Watch, What Will Happen if Hunger Comes? (11.06.2012), $<$ http://www.hrw.org/sites/default/files/reports/ethiopia0612webwcover_0.pdf>, accessed 2 Dec 2016, 1-35.

28 Human Rights Watch, World Report 2017: Ethiopia; Human Rights Watch, World Report 2016: Ethiopia.

29 Human Rights Watch, Human Rights Watch World Report 2015: Ethiopia, <https://www.hrw.org/world-report/2015/country-chapters/ethiopia>, accessed 11 Jul 2018.

30 The Inspection Panel, Notice of Registration Request for Inspection: ETHIOPIA: Protection of Basic Services Program Phase II Project Additional 
The case study discussed in this chapter will focus on the PBS programme which also has some operational linkages with the "villagisation' programme. It illustrates the challenge of striking a fair balance between development and human rights interests and shows how human rights might become a trade-off to benefit other interests. The PBS programme is one of the largest donor programmes in Ethiopia. Launched in 2006, it was conceived as a programme of the Ethiopian government. It has been co-financed by the World Bank, the African Development Bank, the German KfW Bank (until Phase II) ${ }^{31}$ and several bilateral donors including the Austrian Development Agency (ADA). ${ }^{32}$ Its third phase was approved in July 2012 and should be operative until 2019. ${ }^{33}$ The overall costs of the PBS programme have amounted to more than 13 billion USD; 60 per cent of which was contributed by the Ethiopian government and the rest by international donors. ${ }^{34}$

Financing (P121727) and Promoting Basic Services Phase III Project (P128891) IPN REQUEST RQ 12/05, (09.10.2012), <http://siteresources.worldbank.org/ EXTINSPECTIONPANEL/Resources/Ethiopia_PBS_Notice_of_Registration.pdf>, accessed 12 Dec 2016, 4; Human Rights Watch, Waiting Here For Death: Displacement and "Villagization" in Ethiopia's Gambella Region, (2012), <http:// www.hrw.org/sites/default/files/reports/ethiopia0112webwcover_0.pdf>, accessed 3 May 2017, 2-5.

31 Other PBS II donors included the World Bank (IDA), the African Development Bank, Austria, Italy, Canada, GB, the EU, Ireland, Netherlands, Spain, World Bank, World Bank Project Appraisal Document on a Proposed Grant in the Amount of 2075 Million SDR (US\$ 30978 Million Equivalent) and Proposed Credit in the Amount of SDR 1543 Million (US\$ 23022 Million Equivalent) to the Federal Democratic Republic of Ethiopia for a Protection of Basic Services Program Phase II Project Report No: 45186-ET, (22.04.2009) $<$ http://www-wds.worldbank.org/external/default/WDSContentServer/WDSP/IB/ 2009/05/21/000350881_20090521113144/Rendered/PDF/451860PAD0REPL1I LE0IDA1R20091008913.pdf>, accessed 12 Dec 2016.

32 Other PBS III donors include the World Bank, the African Development Fund, GB, the EU, Austria and Italy, African Development Fund, Ethiopia Promoting Basic Services Programme (PBS III) Appraisal Report, (11.07.2012) $<$ http://www.afdb.org/fileadmin/uploads/afdb/Documents/Project-and-Operations/ ETHIOPIA\%20-\%20AR\%20-\%20Promoting\%20Basic\%20Services\%20Programme \%20(PBS\%20III).pdf>, accessed 5 Dec 2016, iv.

33 World Bank, Ethiopia Promoting Basic Services Program Phase III Project Overview, <http://www.worldbank.org/projects/P128891/ethiopia-protectionbasic-services-program-phase-iii-project?lang=en> accessed 13 Jul 2016.

34 The Inspection Panel, Notice of Registration Request for Inspection: ETHIOPIA: Protection of Basic Services Program Phase II Project Additional Financing (P121727) and Promoting Basic Services Phase III Project (P128891) IPN REQUEST RQ 12/05, (09.10.2012), <http://www.anuakjustice.org/down 
The PBS programme has two objectives: The first one is expanding access to and improving the quality of the decentralised delivery of basic services in education, health, agriculture, water supply, sanitation and rural roads. ${ }^{35}$ To achieve this, PBS provides direct budget support in the form of block grants (about 90 per cent of the programme's funding), which are allocated to sub-national woreda administrations. ${ }^{36}$ Woredas are similar to districts, which consist of kebeles similar to neighbourhoods. ${ }^{37}$ The second objective is strengthening Ethiopia's public financial management by enhancing financial reporting, improving transparency and accountability as well as monitoring of the programme. ${ }^{38}$ The key development indicators for monitoring the achievement of PBS objectives are primarily quantitative and include, for example:

the primary school net enrolment rate, the proportion of children vaccinated, the proportion of rural and urban population with access to potable water, the number of farmers trained in the agricultural minimum package, the proportion of kebele centres connected by all-weather roads, the proportion of

loads/121009-Signed-NOR.pdf>, accessed 16 Jul 2018, 2; Development Assistance Group Ethiopia, Aid Management and Utilisation in Ethiopia: A Study in Response to Allegations of Distortion in Donor-Supported Development Programmes, (01.07.2010), <http://dagethiopia.org/new/news-highlights/8-about/ latest-news/54-aid-management-and-utilisation-in-ethiopia-a-study-in-response-toallegations-of-distortion-in-donor-supported-development-programmes $>$, accessed 3 Jul 2018, 13.

35 African Development Fund, African Development Fund Ethiopia - Promoting Basic Services Programme (PBS III) Appraisal Report, (11.07.2012), 12.

36 Development Assistance Group Ethiopia, Aid Management and Utilisation in Ethiopia: A Study in Response to Allegations of Distortion in DonorSupported Development Programmes, (01.07.2010), 13.

37 Human Rights Watch, What Will Happen if Hunger Comes? (11.06.2012) $<$ http://www.hrw.org/sites/default/files/reports/ethiopia0612webwcover_0.pdf>, 32 .

38 African Development Bank Group, Ethiopia - Protection of Basic Services II (PBS) - Programme Completion Report, (29.10.2012) <http://www.afdb. org/fileadmin/uploads/afdb/Documents/Project-and-Operations/Ethiopia\%20\%E2 $\% 80 \% 93 \%$ 20Protection\%20 of\%20Basic\%20Services\%20II\%20(PBS)\%20-\%20 Programme\%20Completion\%20Report\%20(PCR).pdf $>$, accessed 16 Jul 2018, 3, viii; African Development Fund, Ethiopia - Promoting Basic Services Programme (PBS III) Appraisal Report, (11.07.2012), 12; Development Assistance Group Ethiopia, Aid Management and Utilisation in Ethiopia: A Study in Response to Allegations of Distortion in Donor-supported Development Programmes, (01.07.2010), 13. 
citizens who know the woreda budget or being asked by kebele officials about the quality of basic services. ${ }^{39}$

The initial idea of the PBS programme was to sustain the already achieved goals in social indicators before the political crisis in 2005 which entailed a suspension of budget support. The reason for this suspension was that donors were concerned about the diversion of the funds to political constituencies supporting the government. ${ }^{40}$ They decided thus that the PBS programme should no longer rely on the federal level but on sub-national government structures, namely woredas and kebeles, which from that time on should be responsible for basic service support. ${ }^{41}$ The Ministry of Finance and Economic Development (MOFED) and the Bureaus of Finance and Economic Development (BOFEDs) were assigned certain responsibilities at the federal and regional level but local level entities represented by the Woreda Finance and Economic Development Offices (WOFEDs) as well as the Urban Administration Offices of Finance were entrusted with the key tasks which consisted of delivery of service. ${ }^{42}$ The donors argued that this revised programme design would better ensure that 'the funds would be allocated in a fair and accountable

39 World Bank, Project Appraisal Document on a Proposed Grant in the Amount of 207,5 Million SDR (US\$ 30978 Million Equivalent) and Proposed Credit in the Amount of SDR 1543 Million (US\$ 23022 Million Equivalent) to the Federal Democratic Republic of Ethiopia for a Protection of Basic Services Program Phase II Project Report No: 45186-ET, (22.04.2009), <http:// documents.worldbank.org/curated/en/104521468256148995/pdf/451860PAD0RE PL1ILE0IDA1R20091008913.pdf>, accessed 16 Jul 2018, 18.

40 African Development Bank Group, Ethiopia - Protection of Basic Services II (PBS) - Programme Completion Report, (29.10.2012), viii.

41 World Bank, Project Appraisal Document on a Proposed Grant in the Amount of 2075 Million SDR (US\$ 30978 Million Equivalent) and Proposed Credit in the Amount of SDR 1543 Million (US\$ 23022 Million Equivalent) to the Federal Democratic Republic of Ethiopia for a Protection of Basic Services Program Phase II Project Report No: 45186-ET, (22.04.2009), 18; African Development Fund, Ethiopia - Promoting Basic Services Programme (PBS III) Appraisal Report, (11.07.2012), v, 12; Human Rights Watch, What Will Happen if Hunger Comes? (11.06.2012), 32.

42 Development Assistance Group Ethiopia, Aid Management and Utilisation in Ethiopia: A Study in Response to Allegations of Distortion in Donorsupported Development Programmes (01.07.2010), 14; African Development Fund, Ethiopia - Promoting Basic Services Programme (PBS III): Appraisal Report, (11.07.2012), 18; The World Bank, Project Appraisal Document PBS III, Report No: 69689-ET, (29.08.2012), <http://documents.worldbank.org/curated/ en/731661468032393203/pdf/696890PAD0P1280Official0Use0Only090.pdf>, accessed 28 Mar 2019, p. 24. 
manner, without political capture or bias' ${ }^{43}$ This is however exactly the point in which human rights concerns arise.

From a human rights perspective, the donor argument that the local level would be more reliable seems highly questionable bearing in mind the political realities on the ground. Kebele administrations have traditionally had enormous discretionary power over their constituents and have largely controlled access to services. Even before the EPRDF took power, the kebele system had functioned as a highly effective mechanism of control and repression which was used to spread government propaganda and maintain discipline and order. ${ }^{44}$ Nowadays kebele officials are exclusively composed of EPRDF party members. They are in charge of distributing fertilizers, seeds, credit and other essential agricultural services. They equally control access to land, decide on eligibility for food assistance, and are responsible for issuing recommendations for educational opportunities and jobs as well as referring persons to secondary health care facilities. Most of the kebeles also run local tribunals and prisons as well as local militias. ${ }^{45}$ Kebeles therefore dispose of huge discretionary powers. Consisting exclusively of EPRDF members, they are part of the government's control apparatus and act as the local branch of the ruling coalition. Human Rights Watch noted that '[...] Ethiopia's national government created the repressive policies, [but] district governments actually implemented them'. ${ }^{46}$ In reality, kebeles may therefore, contrary to the donor argument, hardly be perceived as partners without political capture and bias. On the contrary, they are highly likely to act in a discretionary way.

In 2010, four years after the beginning of the programme, Human Rights Watch published a striking report which analysed the human rights compliance of the PBS programme as well as other donor-supported programmes in Ethiopia. It found a broad range of human rights

43 African Development Bank Group, Ethiopia - Protection of Basic Services II (PBS) - Programme Completion Report, (29.10.2012), viii.

44 Human Rights Watch, Suppressing Dissent Human Rights Abuses and Political Repression in Ethiopia's Oromia Region, (11.07.2005), <http:// www.hrw.org/sites/default/files/reports/ethiopia0505.pdf>, accessed 13 Dec 2017, 27-8.

45 Human Rights Watch, Ethiopia: Development without Freedom: How Aid Underwrites Repression in Ethiopia, (13.10.2010), 16-17; Human Rights Watch, Suppressing Dissent Human Rights Abuses and Political Repression in Ethiopia's Oromia Region, (11.07.2005), 27, 28.

46 Human Rights Watch, Ethiopia: Development without Freedom How Aid Underwrites Repression in Ethiopia, (13.10.2010), 20, 21. 
violations linked to all of these programmes. ${ }^{47}$ In the case of the PBS programme, it identified a massive prevalence of political distortion of funds that directly impacted people's access to basic needs for survival such as agricultural products, health services or education. ${ }^{48}$ Furthermore it revealed systematic patterns of discrimination against political opponents, who were consistently prevented from getting donor-supported government services. ${ }^{49}$ It equally found systematic abuse of power for political purposes and intimidation by kebele officials. ${ }^{50}$ Farmers for example, were denied access to seeds, fertilizers and other agricultural products due to their political orientation; sometimes they were also arbitrarily deprived of their land.51 Their complaints to aid officials, kebele or woreda leaders were routinely ignored. ${ }^{52}$ Teachers were pressured to join the ruling party and the Ethiopian Teachers' Association was controlled by the government. Those who refused or who joined the independent National Teachers' Association were denied training opportunities and promotion. Positions such as head teacher or accountant were reserved for party members. Teachers and students had to attend compulsory political party trainings. Party membership was also a precondition to entering university..$^{53}$

Overall, the PBS programme was found to contribute to a range of human rights violations concerning freedom from discrimination, the right to food, education, health, property, freedom of assembly, and expression. ${ }^{54}$ Strikingly, the Human Rights Watch report revealed that most donor agencies were fully aware of the discriminatory practices and political diversion of funds. ${ }^{55}$ In 2005, even before the start of the PBS programme, Human Rights Watch had provided substantial evidence for human rights violations through Ethiopia's kebele administration and its police and security forces. It had also underlined that development

47 The Report is based on interviews with more than 200 persons (farmers, rural villagers, urban residents, students, teachers, civil servants, business people, journalists, diplomats, aid officials and politicians) from 53 kebeles (villages or neighbourhoods) in 27 woredas (districts) interviewed between June and December 2009, Human Rights Watch, Ethiopia: Development without Freedom How Aid Underwrites Repression in Ethiopia, (13.10.2010), 10, 30-33.

48 Ibid., 4.

49 Ibid., 5.

50 Ibid., 92.

51 Ibid., 36, 37.

52 Ibid., 92.

53 Ibid., 94-6.

54 Ibid., 26.

55 Ibid., 4. 
objectives were used as a pretext to justify harassment, intimidation or forced labour by administrative structures. ${ }^{56}$ In 2006, even the World Bank had clearly flagged the risk of political capture of aid emphasising that it was critical 'to professionalize and insulate public administration to mitigate the risk that devolved funds and service delivery in the context of decentralisation could be captured for political ends'. ${ }^{57}$ Apparently these warnings did not strengthen the monitoring of civil servants', local government officials' or head teachers' conduct. ${ }^{58}$ Interviews conducted by Human Rights Watch in 2009/2010 reconfirmed that donors were aware of the ongoing politicisation of housing, business and agriculture as well as of the fact that their funds were misused to oppress opponents. ${ }^{59}$ Some even openly acknowledged that existing monitoring mechanisms 'were not able to track the political manipulation of donorsupported services'.60 Despite these facts however, donors kept emphasising Ethiopia's stability, economic development and progress in meeting the MDG goals. ${ }^{61}$

Reacting to the Human Rights Watch report the Ethiopian donors' Development Assistance Group (DAG) commissioned an analysis of the robustness of PBS safeguards. ${ }^{62}$ The report found that allegations of political distortion of aid were not new in Ethiopia. They had been a reoccurring problem over the last 15 years and were particularly evident in those regions where the opposition tended to be strong. Since 2009, the DAG had received allegations of political distortion but had not found conclusive evidence. Frequent complaints included in particular favouring of EPRDF members in hiring and promoting them as teachers or agricultural development agents, and favouring them in the distribution of

56 Human Rights Watch, Suppressing Dissent Human Rights Abuses and Political Repression in Ethiopia's Oromia Region, (11.07.2005), 3-5.

57 International Development Association, Interim Country Assistance Strategy for the Federal Democratic Republic of Ethiopia Report No. 35142ET, (02.05.2006), <http://www-wds.worldbank.org/external/default/WDSContent Server/WDSP/IB/2006/05/16/000090341_20060516102529/Rendered/PDF/351 42.pdf>, updated 2 May 2006, accessed 14 Dec 2017, 8; Human Rights Watch, Ethiopia: Development without Freedom: How Aid Underwrites Repression in Ethiopia, (13.10.2010), 20, 21.

58 Human Rights Watch, ibid., 35.

59 Ibid., 34.

60 Ibid., 5.

61 Ibid.

62 Development Assistance Group Ethiopia, Aid Management and Utilisation in Ethiopia: A Study in Response to Allegations of Distortion in Donorsupported Development Programmes, (01.07.2010), 5, iii. 
fertilizer or the location of health facilities and infrastructure. Furthermore people complained about obliging teachers and agricultural agents to attend political indoctrination events and requiring EPRDF membership for entering university courses. ${ }^{63}$ Overall, the DAG report confirmed therefore that donors had been fully aware of the fact that services co-funded by the PBS programme would run a high risk of being used for political ends and would most likely not be distributed in a fair and equal manner.

At the same time the report found that the safeguards donors had put in place to identify distortion were 'relatively robust' ${ }^{64}$ Donors conducted monthly field missions to verify government reports and participation in decision making processes, distributed financial transparency tools and guidelines, encouraged citizens to hold the government and serviceproviders accountable and ran a survey on users' perceptions of coverage and quality of services. Furthermore, they asked woredas to report any case of exclusion or distortion of services at the local level. Despite these measures the DAG study concluded that progress on social accountability, that is, accountability to project affected people, 'was delayed'. Only some pilot initiatives had started to include funding for Ethiopian civil society organisations to implement reporting tools and citizens' monitoring of services. ${ }^{65}$

The report also admitted that it was a challenge to ensure that programme activities '[helped] to reduce the risk of political distortion at woreda and sub-woreda levels', that the implementation of financial transparency by local authorities was 'variable and that there was a lack of public awareness about how local government and service delivery are supposed to function'. ${ }^{66}$ It underlined that the progress on processes and mechanisms for participation and accountability, which were mainly building on existing government structures, was very slow. ${ }^{67}$ It equally

63 Ibid., 6, 7, 15.

64 Ibid., v.

65 Inclusive Development International, Policy and Legal Analysis of the Ethiopia PBS Request for Inspection, (24.09.2012), <http://www.inclusive development.net/wp-content/uploads/2012/09/Legal-and-Policy-Analysis-forAnuak-Request-for-Inspection.pdf $>$, accessed 6 Jan 2018, 10; Development Assistance Group Ethiopia, Aid Management and Utilisation in Ethiopia: A Study in Response to Allegations of Distortion in Donor-supported Development Programmes, (01.07.2010), 16.

66 Development Assistance Group Ethiopia, Aid Management and Utilisation in Ethiopia: A Study in Response to Allegations of Distortion in Donorsupported Development Programmes, (01.07.2010), v.

67 Ibid. 
noted that donors had not reduced funding in cases of unsatisfactory reports. ${ }^{68}$ The report concluded however that the major challenge for the PBS programme was the capacity constraints of the Ethiopian government structures. ${ }^{69}$

Since 2010, the PBS programme has also been harshly criticised for its supposed linkages to Ethiopia's Commune Development Programme (CDP). This highly controversial 'villagisation' programme has been accompanied by forced evictions, physical assault, disappearances and other severe human rights violations which led to two international complaints: one in front of the World Bank Inspection Panel and the other before the British High Court. ${ }^{70}$

In the Inspection Panel complaint representatives of the indigenous Anuak tribe in the Gambella region, argued that by funding government workers' salaries the PBS Programme has been directly contributing to Ethiopia's 'villagisation programme' which resulted in forced eviction from their ancestral lands. ${ }^{71}$ They claimed that the evictions were accompanied by arbitrary arrests, beatings, assaults, torture, rape and destruction of properties. The new villages to which the community members were transferred offered no fertile land, no clinics, schools or basic services and no humane living conditions. ${ }^{72}$ The complainants were critical that the Bank had not considered the risk of coercive villagisation and forced evictions in its risk assessment despite the fact that the latter constituted a well-known and historically used practice in the context of Ethiopia's development and basic service programmes. Instead, the Bank argued that PBS 'financed only recurring expenditures' and would therefore not fall within the scope of the Bank's operational policies on indigenous peoples and involuntary resettlement. Furthermore, the complainants noted that the Bank had equally refused to listen to Anuak

68 Ibid., 16, 17.

69 Ibid., v.

70 Tesfa News, UK Government Accused of Sponsoring Human Rights Abuses in Ethiopia, (22.01.2015), <http://www.oaklandinstitute.org/uk-governmentaccused-sponsoring-human-rights-abuses-ethiopia-0>, accessed 11 Jul 2018; Human Rights Watch, World Report 2015: Ethiopia, (2015).

71 The Inspection Panel, Notice of Registration, Request for Inspection: ETHIOPIA: Protection of Basic Services Program Phase II Project Additional Financing (P121727) and Promoting Basic Services Phase III Project (P128891) IPN REQUEST RQ 12/05, (09.10.2012), 4.

72 Ibid., 3-5. 
refugees and their testimonials about the situation of the people in the affected regions. ${ }^{73}$

In November 2014, after having examined the facts of the case, the Inspection Panel's investigation report confirmed 'that there [was] an operational link (interface) between the CDP and PBS in the woredas where there [was] concurrent implementation'. ${ }^{74}$ It equally admitted that:

considering the magnitude of the operation, the nature of block grant financing, and the overlapping implementation between PBS III and CDP, [...] World Bank management did not carry out the required full risk analysis, nor were its mitigation measures adequate to manage the concurrent roll-out of the villagisation program in four PBS III regions. ${ }^{75}$

The panel noted however that 'the involuntary taking of land and use of force and intimidation are alleged consequences of the resettlement under CDP but not under PBS'. ${ }^{76}$ Sustaining that the resettlement policy which includes safeguards for project affected individuals did not apply to PBS, it concluded therefore that 'the Bank [was] not responsible for these alleged harms'. ${ }^{77}$ It equally held that the lack of services and the deterioration of livelihoods at relocation sites were 'not a direct consequence of the PBS either'. ${ }^{78}$ Nevertheless the Panel conceded that the operational overlaps between the PBS and the CDP 'should have been recognised and addressed throughout appraisal and during monitoring; if this had happened, there may have been opportunities for PBS to mitigate and manage some of the negative consequences of CDP, especially in the earlier years'.79

\footnotetext{
73 Ibid., 5, 6.

74 World Bank Inspection Panel, Ethiopia: Promoting Basic Services Phase
} III Project (P128891) Investigation Report, Report No. 91854-ET, (21.11.2014), <http://www-wds.worldbank.org/external/default/WDSContentServer/WDSP/IB/ 2015/01/13/000470435_20150113093847/Rendered/INDEX/918540REVISED0 0900INSP0R20140000401.txt>, accessed 16 Jul 2018, para 10; John Lunn, Ethiopia: DFID ends support for the Promotion of Basic Services Programme, SN 07116, (02/03/2015), <http://researchbriefings.parliament.uk/ResearchBriefing/ Summary/SN07116\#fullreport>, accessed 13 Jul 2018.

75 World Bank Inspection Panel, Ethiopia: Promoting Basic Services Phase III Project (P128891) Investigation Report, Report No. 91854-ET, (21.11.2014), para 15.

$\begin{array}{ll}76 & \text { Ibid., para } 310 . \\ 77 & \text { Ibid. } \\ 78 & \text { Ibid. } \\ 79 & \text { Ibid. }\end{array}$ 
The Inspection Panel's findings led to an Action Plan by the Bank management. According to Human Rights Watch however the plan failed to tackle the root causes as it suggested 'officials implicated in human rights abuses as a source of potential resolution' ${ }^{80}$ Thereby it continued to turn a blind eye to one substantial risk for people, namely speaking out critically against the party. ${ }^{81}$

In February 2015, the Bank's Board of Executive Directors discussed the Inspection Panel's investigation report and approved the Management's Action Plan. Referring to the Inspection Panel's findings the Board noted that although '[...] the Bank was not responsible for any harm, [the Inspection Panel] did point out areas where [the Bank] could have done more to help the Anuak people and other vulnerable groups. [...]'. ${ }^{82}$ At the same time the Board reiterated that 'PBS had brought important benefits to help advance the Millennium Development Goals in Ethiopia'.83

The second complaint against the PBS Programme was filed at a UK court. In March 2014, the British law firm Leigh Day on behalf of a farmer from Gambella State (referred to as Mr. O), launched legal proceedings against the Secretary of State for International Development. They claimed that UK's Department for International Development (DFID) 'had unlawfully failed to assess whether UK aid money was involved in the villagisation programme' ${ }^{84}$

$\mathrm{Mr} \mathrm{O}$, who had fled to Kenya, asserted that he and his family had been forcibly evicted by the military and were told to settle in another area. According to Leigh Day:

they were not given new farms or any farmland and there was no food or water available. The few menial jobs to be had did not provide enough income for survival. There was no school and no healthcare facility in the

80 Human Rights Watch, World Bank: Address Ethiopia Findings, Response to Inquiry Dismissive of Abuses, (23.02.2015), <https://www.hrw.org/news/2015/ 02/23/world-bank-address-ethiopia-findings $>$, accessed 13 Aug 2017; Lunn, Ethiopia: DFID ends support for the Promotion of Basic Services Programme, SN 07116, (02.03.2015), 6.

81 Ibid.

82 World Bank Inspection Panel, World Bank Board Discusses Inspection Panel Case in Ethiopia, News Release 2015/143/ECR, (27.02.2015).

83 Ibid.

84 Leigh Day, Lawyers for an Ethiopian man have said he is delighted after the High Court agreed his legal action against the UK government could go to a full hearing. <http://www.leighday.co.uk/News/2014/July-2014/Ethiopian-manwins-right-to-take-legal-case-forwar>, accessed 13 Jul 2018. 
area, both of which had existed in his previous home area. In order to survive, $\mathrm{Mr} \mathrm{O}$ returned to his old village and attempted to continue farming there. Shortly after his return, he was captured by EPRDF soldiers, who took him to a military camp. There he [claimed] he was gagged and then severely beaten for several hours. The soldiers used their rifles and their boots to beat him, causing significant injuries. ${ }^{85}$

The UK is one of Ethiopia's major donors and a substantial contributor to the PBS Programme. Mr O's lawyers argued that:

by contributing to this programme, which supports five sectors of services: health, agricultural support, roads, water and education, [the UK] contributed to the villagisation programme, by financing infrastructure in new settlements for forcibly relocated populations, or by paying the salaries of district officials overseeing and implementing the villagisation programme. ${ }^{86}$

Highlighting the tragic impact of the programme on $\mathrm{Mr} \mathrm{O}$ and his family they requested DFID to 'properly investigate and take immediate steps to ensure UK aid money is not involved'. ${ }^{87}$ They equally requested it to 'be open and transparent about the findings of such investigations and to encourage and allow other organisations to feed their evidence into this process'.88

In July 2014, the British High Court ruled that Mr O's case should go to a full hearing. Leigh Day reported on the court's reasoning as follows:

In his judgment Mr Justice Warby said the policies 'acknowledge the need for governments which are partners in the grant and receipt of aid to respect and uphold human rights, and the need for the UK Government as a donor to reconsider aid decisions if recipient countries are found to be in significant violation of human rights'. He ruled that $\mathrm{Mr} \mathrm{O}$ had an arguable case against the Government on the basis that the Secretary of State 'has failed to have in

85 Leigh Day, Legal action begins against DFID over alleged Ethiopian rights abuses, Leigh Day issues proceedings in High Court on human rights abuse allegations in Ethiopia, <http://www.leighday.co.uk/News/2014/March2014/Legal-action-begins-against-DFID-over-alleged-Ethi>, accessed 13 Jul 2018; UK High Court of Justice, $R(O) v$ Secretary of State for International Development, Case No: CO/676/2014, Judicial review of DFID's failure properly to investigate the apparent use of UK aid money for human rights abuses in Ethiopia. [2014] EWHC 2371 (QB) <https://files.monckton.com/wp-content/ uploads/2014/07/27103604/R-O-v-Secretary-of-State-for-International-Development. pdf>, accessed 25 May 2019.

86 Ibid.

87 Ibid.

88 Ibid. 
place any sufficient process to assess Ethiopia's compliance with the express conditions for receiving UK aid - or to follow such process' ${ }^{89}$

Warby equally found that the Secretary of State had acted unlawfully since she refused to publish the impact assessment of the PBS programme and therefore violated transparency policies..$^{90}$

Yet, before the end of the full hearing and before the Court could issue a judgement, DFID, which had always denied any linkages to villagisation, suddenly withdrew from the project. In February 2015, it announced that it intended to reconfigure its bilateral programme with Ethiopia and to evolve its strategy by ending its support for the PBS programme. ${ }^{91}$ According to The Guardian, DFID explained in court that its withdrawal:

was as a result of ongoing concerns related to civil and political rights at the level of the overall partnership in Ethiopia, and in particular recent trends on civil and political rights in relation to freedom of expression and electoral competition, and continued concerns about the accountability of the security services. [...] In light of these concerns about Ethiopia's record on civil and political rights, and the trend of that record, it was decided to review the way in which UK aid was provided to Ethiopia. [...] As a result, [it] had chosen to support programmes involving 'a lesser degree of responsibility and authority of the government of Ethiopia than the PBS'. ${ }^{92}$

In March 2015, subsequent to these events, also $\mathrm{Mr} \mathrm{O}$ dropped his claim for judicial review of DFID's actions. His lawyers maintained that 'he had got everything he had hoped to achieve from his litigation' ${ }^{93}$ They underlined that he never strived for compensation but only wanted to make sure that the financial support for this programme which had devastating effects on his family was ended. ${ }^{94}$

89 'Ethiopian man wins right to take legal case forward' <https://www. leighday.co.uk/News/2014/July-2014/Ethiopian-man-wins-right-to-take-legal-caseforward $>$ accessed 29 July 2019.

90 Lunn, Ethiopia: DFID ends support for the Promotion of Basic Services Programme, 5.

91 Ibid., 3.

92 Sam Jones, Ethiopian farmer drops case alleging UK aid helped fund evictions, (06.03.2015) <http://www.theguardian.com/global-development/ 2015/mar/06/ethiopian-farmer-drops-case-dfid-alleging-aid-money-helped-fundevictions>, accessed 13 Jul 2018.

93 Ibid.

94 Ibid. 
From a legal point of view, this case constituted a highly interesting and pioneering attempt to require home state accountability for extraterritorial human rights violations resulting from a development project. The UK court's reasoning and response could have been a key contribution for further defining home state accountability in this regard. Unfortunately politics seems to have been faster than the judiciary. The PBS programme however continues to be implemented with the support of other donors. It remains to be seen to what extent the Inspection Panel and High Court complaints have resulted in improving the human rights situation or whether we will soon see new legal complaints which will then proceed to be decided on the merits.

From a human rights point of view, the PBS programme raises a broad range of questions. It illustrates not only that development and human rights perspectives may substantially differ but also that a development project may be considered successful although it contributes at the same time to human rights violations. Most strikingly, it seems that the human rights violations were part of a calculated risk which was apparently accepted by the donor community to benefit an overall positive development record. The diversion and unequal distribution of PBS services was not seen as being rooted in the underlying authoritarian government structures and the lack of political will, but was boiled down to Ethiopia's lack of capacity.

Equally perspectives differ with regard to monitoring progress, particularly with regard to what is monitored, how and by whom. Independent third-party monitoring on human rights relevant issues seems largely absent. Development indicators are primarily quantitative and fail to provide human rights-relevant information, for example, on equal and unbiased access to services or forced evictions. Strikingly, woredas are expected to report on their own failures and citizens are encouraged to hold the government accountable. Bearing in mind Ethiopia's climate of repression and intimidation however, people will rarely complain about administrative misconduct.

In sum, the PBS programme thus reveals a range of challenges and dilemmas donors may face when they cooperate with weak or undemocratic governance structures. This study does not argue that there exists any easy solution to those multiple challenges. It questions how these challenges may be comprehensively addressed and how a fair balance between human rights and other interests can be found. From a human rights perspective, the case of the PBS programme in Ethiopia raises two principal questions: 
1. Why were well-known human rights concerns constantly put aside and not adequately taken into account in the project design and monitoring?

2. Who may be held accountable by the affected persons such as $\mathrm{Mr} \mathrm{O}$ for the forced evictions, discriminatory distribution of services and other human rights violations occurring in the context of the PBS programme?

In order to consider the first question, we will take a closer look at the relationship between human rights and development cooperation. The second question will be addressed by the in-depth legal analysis in Part II of this book.

\subsection{HUMAN RIGHTS AND DEVELOPMENT COOPERATION: A DIFFICULT MARRIAGE}

The relationship between the development system and the human rights system has traditionally been a difficult one. This chapter will provide insights on why human rights aspects may have been constantly marginalised in the PBS programme and continue to be marginalised in a range of other development undertakings, particularly economic ones.

Human rights and development cooperation emerged as two historically independent systems with opposite interests. For decades, the development enterprise operated in perfect isolation, if not ignorance, of the human rights system and its implications for development, ${ }^{95}$ and vice versa, the human rights community also remained largely agnostic in

95 Peter Uvin, From the Right to Development to the Rights-Based Approach: How Human Rights Entered Development, Development in Practice Vol. 17, No. 4/5 (Aug, 2007), 597; Asbjorn Eide, Human Rights-Based Development in the Age of Globalization, in Bard A. Andreassen and Stephen P. Marks (eds), Development as a Human Right. Legal, Political and Economic Dimensions (2nd edn., Antwerp - Oxford - Portland: Intersentia, 2010), 310; Bonny Ibhawoh, The Right to Development: The Politics and Polemics of Power and Resistance, Human Rights Quarterly, 33/1 (2011), 76-104<http://resolver.ebsco host.com.ludwig.lub.lu.se/openurl?sid=EBSCO:edsjsr\&genre=article \&issn $=0275$ 0392 $\&$ isbn $=\&$ volume $=33 \&$ issue $=1 \&$ date $=20110201 \&$ spage $=76 \&$ pages $=\&$ title $=$ Human\%20Rights \%20Quarterly\&atitle=The $\% 20$ Right $\% 20$ to $\% 20$ Development $\% 3 \mathrm{~A} \% 20 \mathrm{The} \% 20$ Politics $\% 20$ and $\% 20$ Polemics $\% 20$ of $\% 20$ Power $\% 20$ and $\% 20$ Resistance\&btitle=Human $\% 20$ Rights $\% 20$ Quarterly\&jtitle=Human $\% 20$ Rights $\%$ 20Quarterly\&series=\&aulast=Bonny\%20Ibhawoh\&id=DOI:10.1353/hrq.2011.0 001>, accessed 31 Oct 2016, 81 . 
matters of capacity building and economic development. ${ }^{96}$ One of the most striking examples for the disconnection of both worlds was Rwanda's genocide in 1994. Peter Uvin has described the situation as a 'decisive moment when the development community started to pose itself fundamental questions about its role and self-conception' $97 \mathrm{He}$ noted that:

Rwanda had been considered, until close to the break out of the conflict, a model developing country, doing well on the variables we care about: decent macroeconomic growth, the presence of a great number of NGOs and Peasants' associations, high vaccination rates, and the like. [...] Yet, within a few months it would fall apart in a spasm of violence and destruction, the consequences of which it struggles with until today. If our model pupils turn out to be serial killers [...] what does it say about our understanding of what we are doing in the development world? Why are we so blind to local dynamics of power, politics, violence and exclusion? [...] What are the interactions between our presence - the resources, discourses and practices of the development enterprise - and the dynamics that led to genocide?98

Nowadays these questions have been extensively discussed and awareness has increased. However, this does not necessarily mean that the answers have been found. There still exists a deeply rooted scepticism within the development and human rights communities against each other which is often based on a lack of exchange and mutual noncommunication. Legal concepts such as the human rights-based approach to development have been elaborated but its practical implementation still poses many challenges and is far from being common practice on the ground. Many so-called 'development programmes' continue to be based on a purely economic perspective of development. Some examples will be discussed in the chapter on host state responsibility.

The difficult relationship between development and human rights may be traced back to three major root causes. The first lies in their traditional subjects of interest. The idea of human rights originated as a struggle for

96 Peter Uvin, Human Rights and Development (Bloomfield, CT: Kumarian Press, 2004), 47, (2013); Jakob Kirkemann Boesen and Hans-Otto Sano, 'The Implications and Value Added of a Human Rights- Based Approach', in Andreassen and Marks (eds) Development as a Human Right. Legal, Political and Economic Dimensions, 55; Philip Alston, Ships Passing in the Night: The Current State of the Human Rights and Development Debate seen through the Lens of the Millennium Development Goals, <http://www.jstor.org.ludwig.lub.lu. se/stable/20069811>, accessed 31 Oct 2016, 827.

97 Uvin, ibid., 2.

98 Ibid. 
individual rights and freedoms against state oppression in the Age of Enlightenment and has constantly developed in response to major social and political events. ${ }^{99}$ It recognises all human beings as right holders endowed with natural, inherent and inalienable rights that ensure individual freedom, dignity and equality. Human rights have traditionally focused on political and social issues, such as participation, equality or the satisfaction of basic needs. ${ }^{100}$ Development theories, on the contrary, are a much younger concept. They have grown out of the decolonisation process in the 1960s and have traditionally been dealing with general processes of change as well as control of, conflict over and allocation of resources. The development discourse has frequently been used as a foreign policy instrument whereby, social aspects usually appeared as secondary concerns. This was particularly evident during the Cold War but has, in altered forms, continued to date. ${ }^{101}$

The second root cause lies in the fact that development and human rights have been represented by two independent institutional systems. Human rights have been strongly driven by grassroots organisations and legal thinking. They have been defined and interpreted by the United Nations Human Rights bodies, regional and national human rights courts, and human rights institutions. Development policies on the contrary have been characterised by economic, sociological and political thinking. They have grown out of the World Bank and the United Nations Development Program. ${ }^{102}$

99 Hans Otto Sano, Development and Human Rights: The Necessary but Partial Integration of Human Rights and Development, Human Rights Quarterly, 22/3 (2000), 734-52 <http://www.jstor.org/stable/4489299>, accessed 31 Oct 2016, 736-42.

100 Nowak, Introduction to the International Human Rights Regime, (2nd edn, Leiden/Boston: Martinus Nijhoff Publishers, 2003), 9.

101 Sano, Development and Human Rights: The Necessary but Partial Integration of Human Rights and Development, (2000), 736-42; Nuscheler, Entwicklungspolitik, (2005), 77-85; Uvin, Human Rights and Development, (2004), 12.

102 Sano, Development and Human Rights: The Necessary but Partial Integration of Human Rights and Development, (2000), 736-42; Elvira Domínguez Redondo, The Millennium Development Goals and the human rights based approach: reflecting on structural chasms with the United Nations system, International Journal of Human Rights, 13/1 (2009) <http://www.tandfonline. com.ludwig.lub.lu.se/doi/pdf/10.1080/13642980802532317>, accessed 31 Oct 2016, 36; Andrea Cornwall and Celstine Nyamu-Musembi, Putting the 'RightsBased Approach' to Development into Perspective, Third World Quarterly 25/8 (2004), 1422. 
Finally:

development and human rights have been following different professional ethics and quality criteria. The development community has been measuring quality in terms of effective and goal-oriented transfer of resources, increasing social independence and global equality. The human rights community, on the contrary, has been measuring quality in terms of the establishment and incorporation of human rights norms and legal rules in a given culture. ${ }^{103}$

Convergence and constructive dialogue between development and human rights began only in the beginning of the 1990s, after the end of the Cold War. At that time, development thinking started to shift from the conventional economic growth-oriented model to a human development model, which focuses on enhancing human capabilities and acknowledges intrinsic and mutually reinforcing links between development and human rights. ${ }^{104}$ Today this is most clearly expressed in the human rights-based approach. Historically, the convergence between human rights and development may be seen from a political and a legal point of view. From a political perspective it started a long time before, with the struggle for rights and independence during the decolonisation movements. The battles against oppression gave a strong impetus to the concept of rights as a means to achieve social justice. ${ }^{105}$ Already in the late 1950s, developing countries began to demand a 'New International Economic Order' (NIEO) ${ }^{106}$ and called for fundamental changes in North-South relations, in particular fair and equitable trade, better access to the markets and more development aid. The right to self-determination and the principle of sovereign equality became key tools to exercise political pressure. ${ }^{107}$

From a legal perspective, convergence was driven by a number of international declarations and resolutions that aimed at anchoring human rights in development. ${ }^{108}$ The UN Charter in 1945 laid a first basis for linking human rights and development when it required the UN to

103 Sano, ibid.

104 Bart Andreassen and Stephen P. Marks, Development as a Human Right.

Legal Political and Economic Dimensions, (2010), xxvi-xxx.

105 Cornwall and Nyamu-Musembi, Why Rights, Why Now? Reflections on the Rise of Rights in International Development Discourse, (2005), 1420, 1421.

106 Eide, Human Rights-Based development in the Age of Globalization, (2010), 282-3; Ibhawoh, The Right to Development: The Politics and Polemics of Power and Resistance, (2011), 81.

107 Eide, ibid.; Nuscheler, Entwicklungspolitik, (2005), 123.

108 Eide, ibid., 293. 
promote 'higher standards of living, full employment, and conditions of economic and social progress and development $[\ldots]$ and universal respect for and observance of human rights and fundamental freedoms'. ${ }^{109}$ In 1948, the Universal Declaration of Human Rights (UDHR) further emphasised that "everyone is entitled to a social and international order in which the rights and freedoms set forth in the Declaration can be fully realised'. ${ }^{110}$ Some legal scholars have considered this provision as the foundation for a rights-based development as it calls for a transformation of the international order to benefit global equity. ${ }^{111}$

In 1966, the ICESCR included a concrete obligation to pursue human rights-based development in particular with regard to economic, social and cultural rights by requiring that:

each state party $[\ldots]$ undertakes to take steps, individually and through international assistance and co-operation, especially economic and technical, to the maximum of its available resources, with a view to achieving progressively the full realisation of the rights recognised in the present Covenant by all appropriate means, including particularly the adoption of legislative means. ${ }^{112}$

In 1968, the first International Conference on Human Rights held in Teheran acknowledged that '[...] the enjoyment of economic and social rights is inherently linked with any meaningful enjoyment of civil and political rights and that there is a profound inter-connection between the realisation of human rights and economic development [...]'. ${ }^{113}$ It further emphasised ' $[\ldots]$ the collective responsibility of the international community to ensure the attainment of the minimum standard of living necessary for the enjoyment of human rights and fundamental freedoms by all persons throughout the world' ${ }^{114}$ However, despite these solemn

109 United Nations, Charter of the United Nations, (01/01/1945), <http:// www.un.org/en/documents/charter/index.shtml>, accessed 15 Jul 2018, art 55.

110 United Nations General Assembly, Universal Declaration of Human Rights (UDHR), (01/01/1948), art 28.

111 Eide, Human Rights-Based development in the Age of Globalization, (2010), 299.

112 United Nations, International Covenant on Economic Social and Cultural Rights (ICESCR), (01/01/1966), <https://www.ohchr.org/en/professionalinterest/ pages/cescr.aspx>, accessed 16 Jul 2018, art 2.

113 United Nations, Final Act of the International Conference on Human Rights, (01.01.1968), <http://legal.un.org/avl/pdf/ha/fatchr/Final_Act_of_Tehran Conf.pdf>, accessed 4 May 2018, 14.

114 Ibid. 
promises, development practice continued to be based on the conventional growth concept aiming at the expansion of gross national products (GNP), industrialisation, export growth, and capital inflows.

Only in the late 1970s, when it became clear that the growth model had manifestly failed to reduce the continuous expansion of poverty, did fundamental criticism to neo-liberalism triggered a substantial paradigm shift towards the inclusion of social issues in development thinking. It resulted in the prioritisation of the fight against poverty. ${ }^{115}$ The North expressed this new paradigm with the proclamation of the 'basic needs approach' which aimed at identifying and satisfying the basic needs of human development such as health or housing. The basic needs approach however did not yet imply the existence of duty bearers, who were legally accountable to rights holders but relied on benevolent and charitable actions. ${ }^{116}$ The South, in contrast, pursued its own path. It mistrusted the basic needs approach as it feared hidden economic hurdles resulting from its environmental and social requirements and continued therefore to insist on the NIEO. ${ }^{117}$ In 1974, it finally achieved the adoption of the NIEO Declaration, which enshrined the principles of self-determination, equity, effective participation in international economic and political processes, sovereignty over natural resources and economic activities as well as international solidarity and cooperation towards economic and social development. ${ }^{118}$

However, on the operational level both attempts ultimately failed to strengthen human rights on the ground. The basic needs approach amounted to little more than an enthusiastically re-conceptualised strategy and policy papers, and only some of the poorest developing countries could ultimately benefit from the new agenda. The NIEO Declaration turned out to be a 'commodity agreement' whose operationalisation was

115 Andreassen and. Marks, Development as a Human Right: Legal Political and Economic Dimensions, xxiii; Ibhawoh, The Right to Development: The Politics and Polemics of Power and Resistance, (2011), 81.

116 Urban Jonnson, Human Rights Approach to Development Programming, (01.01.2003), <http://www.unicef.org/rightsresults/files/HRBDP_Urban_Jonsson _April_2003.pdf>, accessed 16 Jul 2018, 20-21; Nuscheler, Entwicklungspolitik, (2005), 77-85.

117 Nuscheler, ibid., 80.

118 United Nations General Assembly, Declaration on the Establishment of a New International Economic Order A/RES/S-6/3201, (01/05/1974) <http://www. un-documents.net/s6r3201.htm> accessed 03 Nov. 2016. 
ultimately hampered by differing interests between North and South but also among developing countries themselves. ${ }^{119}$

One of the most promising attempts to link human rights and development was certainly the right to development. In 1977, the UN Commission on Human Rights for the first time recognised development as a human right and subsequently established a working group to come up with effective means for its operationalisation. ${ }^{120}$ In 1981, the right to development was first referred to in the African Charter on Human and Peoples' Rights, which constituted a major achievement of the decolonialisation process. ${ }^{121}$ It marked an important paradigm shift from traditional human rights thinking as it included not only individuals but, for the first time, also collective claims. Those include for example the right of all peoples to equality, the right to self-determination, the right to dispose freely of their wealth and natural resources as well as the right to economic, social and cultural development, the right to national and international peace and security and the right to a satisfactory environment. ${ }^{122}$ These promising developments were unfortunately harshly interrupted by the economic crisis that hit the developing world in the 1980s. It entailed years of rigid structural adjustment programmes, which often resulted in adverse human rights consequences for the people in developing countries. ${ }^{123}$

119 Nuscheler, Entwicklungspolitik, (2005), 80; United Nations General Assembly, ibid.; Uvin, Human Rights and Development, (2004), 41.

120 OHCHR, Background on the Right to Development, <http://www.ohchr. org/EN/Issues/Development/Pages/Backgroundrtd.aspx>, accessed 4 Jun 2016.

121 Organisation of African Unity, African Charter on Human and Peoples' Rights, (27/06/1981), <http://www.achpr.org/instruments/achpr/>, accessed 16 Jul 2018.

122 Ibid., arts 19, 20, 21, 22, 23, 24; Uvin, Human Rights and Development, (2004), 14.

123 Nuscheler, Entwicklungspolitik, (2005), 77-85, 125; Uvin, From the Right to Development to the Rights-Based Approach: How Human Rights Entered Development, 597; Committee on Economic Social and Cultural Rights, Concluding observations of the Committee on Economic Social and Cultural Rights: Brazil, E/C. 12/1/Add.87, (26.06.2003), <http://docstore.ohchr.org/SelfServices/ FilesHandler.ashx ?enc=4s1Q6QSmlBEDzFEovLCuWzVCXkRUT2pEFOZi2eiiY 16UxHSLwh8vQ838JyKnWQRGV3\%2fBlAs55CRo\%2bjVBVEpgLEJRIcisWos jA0FUXJaxbf3OugNcPI\%2bLtXuOcz3\%2f\%2bEnK>, accessed 27 Jun 2018, para 16; Committee on Economic Social and Cultural Rights, Concluding observations of the Committee on Economic Social and Cultural Rights: Honduras, E/C.12/1/Add.57, (21.05.2001), <http://docstore.ohchr.org/SelfServices/Files Handler.ashx?enc=4slQ6QSmlBEDzFEovLCuWzVCXkRUT2pEFOZi2eiiY15\%2 
Only in 1986 could a new consensus be reached which finally led to the adoption of the Declaration on the Right to Development. This defines the individual and collective right to development as 'an inalienable human right by virtue of which every human person and all peoples are entitled to participate in, contribute to, and enjoy economic, social, cultural and political development, in which all human rights and fundamental freedoms can be fully realised'.124 Moreover, it recognises development as a comprehensive economic, social, cultural and political process on the basis of all individuals' 'free and meaningful participation'. ${ }^{125}$ Thereby, 'the human person becomes the central subject of development that should be its active participant and beneficiary'.126

The Declaration states that as primary duty bearers, states are bound to 'ensure equal access to basic resources, such as education, health services, food or housing, to eradicate social injustices and massive human rights violations, and to promote international peace and security'. ${ }^{127}$ Notably, it already underlines the human rights responsibilities of other actors, in particular non-state actors and the international community. ${ }^{128}$ For a long time however this progressive approach was heavily opposed by industrialised countries as they feared the development of extraterritorial obligations. The right to development could therefore only be unanimously readopted at the Second World Conference on Human Rights in Vienna in 1993. ${ }^{129}$ The Vienna Declaration and Program of Action finally 'reaffirmed the right to development, as established in the Declaration on the Right to Development'. ${ }^{130}$

fgKXY8er\%2foe11Qh5jyL8yt2sNgWyAb70Of6kP3TCB\%2fixoqJ\%2fSWni3SX n3GfNBMeybRPwVhNPE\%2fUoopNDAyp54>, accessed 27 Jun 2018, para 10.

124 United Nations General Assembly, Declaration on the Right to Development, (01.01.1986), <http://www.un.org/documents/ga/res/41/a41r128.htm>, accessed 16 Jul 2018, para 1.

125 Ibid., preamble.

126 Ibid., art 2 para 3, art 8 para 2.

127 Ibid., art 5, art 7 , art 8 para 1.

128 Ibid., art 3, art 4, art 6 para 1.

129 Hamm, A Human Rights Approach to Development, (2001), 1009; Uvin, Human Rights and Development, (2004), 41-3; Cornwall and Nyamu-Musembi, Putting the 'Rights-Based Approach' to Development into Perspective, (2004), 1422.

130 United Nations General Assembly, Vienna Declaration and Program of Action A/CONF.157/23, (01.01.1993), <http://www.un.org/en/development/desa/ population/migration/generalassembly/docs/globalcompact/A_CONF.157_24.pdf>, accessed 16 Jul 2018, para 1.10 . 
From the 1990s onwards, a series of international conferences including the World Summit for Social Development and the Fourth World Conference on Women in 1995, the World Food Summit in 1996, the Millennium Summit in 2000, the World Social Summit in 2002, the MDG Summit 2010 and most recently the Rio +20 UN Conference on Sustainable Development reiterated the right to development in various contexts. ${ }^{131}$ At the UN level, the right to development has been advanced by Arjun Sengupta who was appointed as Independent Expert on the Right to Development (1998-2004), a High-Level Task Force on the Implementation of the Right to Development (2004-2010) ${ }^{132}$ and an open-ended working group (1998-to date). ${ }^{133}$ However, despite these efforts and the hope that this concept would bring clarification to the complex relationship between human rights and development, its legal and political dimensions have remained highly contested. ${ }^{134}$

131 Arjun Sengupta, The Human Right to Development, in Andreassen and Marks (eds), Development as a Human Right: Legal, Political and Economic Dimensions (2010), 14; Ibhawoh, The Right to Development: The Politics and Polemics of Power and Resistance, (2011), 92; United Nations General Assembly, Keeping the Promise: United to Achieve the Millennium Development Goals, A/RES/65/1, (24.01.2011), <http://www.un.org/en/mdg/summit2010/pdf/outcome _documentN1051260.pdf $>$, accessed 18 Nov 2016; United Nations General Assembly, The Future we want A/RES/66/288, (13.09.2012), <http://www.un.org/ en/development/desa/population/migration/generalassembly/docs/globalcompact/ A_RES_66_288.pdf>, accessed 18 Nov 2016; United Nations General Assembly, Report of the World Summit for Social Development, A/CONF.166/9, (06.03.1995), <https://undocs.org/A/CONF.166/9>, accessed 18 Nov 2016; The Food and Agriculture Organization of the United Nations (FAO), Rome Declaration on World Food Security, (13.11.1996), <http://www.fao.org/wfs/index_ en.htm>, accessed 18 Nov 2016; World Summit on Sustainable Development, Johannesburg Declaration on Sustainable Development A/CONF.199/20 Johannesburg, <http://www.un-documents.net/jburgdec.htm>, accessed 18 Jul 2018; United Nations General Assembly, United Nations Millennium Declaration A/55/L.2, (2000), <http://www.un.org/millennium/declaration/ares552e.htm>, accessed 18 Nov 2018.

132 OHCHR, High-Level Task Force on the implementation of the right to development, <http://www.ohchr.org/EN/Issues/Development/Pages/HighLevel TaskForce.aspx $>$ accessed 3 Nov 2016.

133 OHCHR, The Intergovernmental Working Group on the Right to Development, <http://www.ohchr.org/EN/Issues/Development/Pages/WGRightTo Development.aspx> accessed 3 Nov 2016.

134 Philip Alston, Ships Passing in the Night: The Current State of the Human Rights and Development Debate seen through the Lens of the Millennium Development Goals, 798. 
From a legal point of view, the right to development has been suffering from substantial deficiencies and its status has remained unclear. Some scholars have considered it as a 'synthesis of all human rights rather than a right of its own' ${ }^{135}$ and have therefore negated its justiciability. ${ }^{136}$ The Declaration has also been criticised for failing to identify concrete duty bearers and for embracing different concepts of development. ${ }^{137}$ Critical voices have perceived it rather as a 'bloodied compromise between the industrialised North and the developing South'138 or as a 'rhetorical victory rather than a substantial paradigm shift' 139 , whereby 'the Third World got its right to development, while the First World ensured that the right could never be interpreted as a greater priority than civil and political rights, that it was totally non-binding, and that it carried no resource transfer obligations'. ${ }^{140}$ The right to development does not refer to the NIEO's key issues such as the inequities in world trade, the undemocratic nature of multilateral institutions, or the percentage of GNP that industrialised countries should provide for assistance to developing countries. ${ }^{141}$

The Declaration formally recognises the poor as rights holders and no longer considers them as passive recipients of assistance which was a crucial step. Yet, given the non-binding character of the Declaration its effects on empowerment amount to little more than a pious aspiration. So far, no mechanisms have been put in place where individuals or groups of individuals can file a complaint raising a violation of their right to development. ${ }^{142}$ Proposals such as 'development compacts', which aim at

135 Hamm, A Human Rights Approach to Development, (2001), 1009.

136 Sano, Development and Human Rights: The Necessary but Partial Integration of Human Rights and Development, (2000), 738; Andreassen and Marks, Development as a Human Right: Legal Political and Economic Dimensions, (2010), xxiii; Uvin, Human Rights and Development, (2004), 42-3.

137 Hamm, A Human Rights Approach to Development, (2001), 1009; Uvin, ibid., 43.

138 Thomas W. D. Davis, The Politics of Human Rights and Development: The Challenge of Official Donors, Australian Journal of Political Science, 44/1 (2009), <http://eds.a.ebscohost.com.ludwig.lub.lu.se/eds/pdfviewer/pdfviewer? vid=43\&sid=72602e45-b2bd-4ea6-8fdd-64781f7edd4c\%40sessionmgr4006>, accessed 31 Oct 2016, 176, 177.

139 Uvin, Human Rights and Development, (2004), 41-3.

140 Ibid.

141 Davis, The Politics of Human Rights and Development: The Challenge of Official Donors, 176, 177; Cornwall and Nyamu-Musembi, Putting the 'RightsBased Approach' to Development into Perspective, (2004), 1422.

142 Davis, ibid,, 176. 
setting up a monitoring system within all countries engaged in the cooperation, have not yet been operationalised. ${ }^{143}$ At the moment, only very limited oversight is exercised by the UN Human Rights Council via the universal periodic reviews, and the Committee on Economic, Social and Cultural Rights. ${ }^{144}$

On the political level, the right to development has been heavily instrumentalised in the North-South dialogue by both sides. The debates however served to draw the lines between the parties rather than increase the understanding of the relationship between development and human rights. ${ }^{145}$ Both parties used the rights discourse to pursue their own interests. The South invoked the right to development to demand radical changes on the global economic level and to claim development assistance. At the same time however, it equally drew on this right to justify and maintain internal static political and economic agendas. The North did exactly the opposite. It has traditionally opposed extraterritorial obligations to provide foreign aid and has continuously emphasised the domestic responsibilities of developing countries as a precondition to engage in subsequent changes in global trade and finance. In the end, the debates on the right to development served to legitimise power rather than to reinforce the mutual understanding between development and human rights. ${ }^{146}$ Many scholars have seen the right to development more as a creation of the UN, discussed in some 'obscure UN sub-committee' than as a substantial reference for development practice. ${ }^{147}$ This has also been reflected in leading donor polices ${ }^{148}$ which are quite reluctant to refer to the right to development in their strategies and programmes.

From a broader perspective of social change, the discussions on the right to development have certainly nevertheless impacted human rights

\footnotetext{
143 Sengupta, The Human Right to Development, (2010), 43, 44.

144 Davis, The Politics of Human Rights and Development: The Challenge of Official Donors, (2009), 176.

145 Hamm, A Human Rights Approach to Development, (2001), 1009; Ibhawoh, The Right to Development: The Politics and Polemics of Power and Resistance, (2011), 77.

146 Ibhawoh, The Right to Development: The Politics and Polemics of Power and Resistance, (2011), 78-80, 89-98.

147 Davis, The Politics of Human Rights and Development: The Challenge of Official Donors, (2009), 176, 177; Uvin, Human Rights and Development, (2004), 43; Cornwall and Nyamu-Musembi, Putting the 'Rights-Based Approach' to Development into Perspective, (2004), 1423.

148 See e.g., DIFID, SIDA.
} 
and development thinking. ${ }^{149}$ They have ultimately contributed to establishing a new paradigm that firmly anchors human rights within the development realm. ${ }^{150}$ They have equally extended the thinking on human rights responsibilities of non-state actors and the international community. ${ }^{151}$ In sum they may therefore be seen as a contribution to clarify concepts and challenge orthodoxies. ${ }^{152}$

For development and human rights' workers the abstract debates on the right to development provided little support to solving problems on the ground. They therefore engaged in vital discussions on how to integrate human rights into development practice. This marked the beginning of a new human rights-based approach to development which offered a convenient alternative for distancing the discourse from the complicated political debates on the right to development. ${ }^{153}$

In retrospect, the development of the human rights-based approach was certainly also driven and enabled by the interaction of a range of political and practical factors. The end of the Cold War allowed for a new perspective on human rights as they were no longer instrumentalised to underpin capitalist and communist ideologies. ${ }^{154}$ Critical voices were finally heard. International NGOs, United Nations International Children's Emergency Fund (UNICEF) and UNDP had repeatedly highlighted the adverse human rights effects of the economic development focus as well as the lack of cooperation between development and human

149 Amartya Sen, Human Rights and Development, in Andreassen and Marks, Development as a Human Right. Legal, Political and Economic Dimensions, (2010), 9 .

150 Ibhawoh, The Right to Development: The Politics and Polemics of Power and Resistance, (2011), 103.

151 Cornwall and Nyamu-Musembi, Putting the 'Rights-Based Approach' to Development into Perspective, (2004), 1422.

152 Hamm, A Human Rights Approach to Development, (2001), 1009; Ibhawoh, The Right to Development: The Politics and Polemics of Power and Resistance, (2011), 77-8.

153 Cornwall and Nyamu-Musembi, Putting the 'Rights-Based Approach' to Development into Perspective, (2004), 1424; Alston, Ships Passing in the Night: The Current State of the Human Rights and Development Debate seen through the Lens of the Millennium Development Goals, (2005), 798, 799; Kirkemann Boesen and Sano, The Implications and Value Added of a Human Rights-Based Approach, (2010), 56.

154 Sano, Development and Human Rights: The Necessary but Partial Integration of Human Rights and Development, (2010), 740; Eide, Human RightsBased development in the Age of Globalization, (2010), 310; Hamm, A Human Rights Approach to Development, (2012), 1006. 
rights on the operational level. ${ }^{155}$ In 1990, the UN Committee on Economic, Social and Cultural Rights explicitly acknowledged that ' $[\ldots]$ development cooperation activities do not automatically contribute to the promotion of respect for economic, social and cultural rights'. ${ }^{156}$ It noted that "many activities undertaken in the name of "development" have subsequently been recognised as ill-conceived and even counterproductive in human rights terms' ${ }^{157}$

In 1993, the Vienna World Conference on Human Rights and its Declaration and Program of Action recognised all human rights as universal, indivisible, interdependent and interrelated values and significantly raised the profile of economic, social and cultural rights. ${ }^{158}$ This provided an important basis for extending the human rights regime 'toward other duty bearers and new methods and means of accountability that went beyond strict legal procedures'. ${ }^{159}$ It equally generated new ideas for the human rights-based approach to development.

Furthermore, development practice had come to a crisis. Structural adjustment programmes had manifestly failed and in many cases undermined the human rights situation. The root cause was mainly seen in a lack of government accountability which prompted a push for democracy and good governance. ${ }^{160}$ Democracy was linked to the protection of individual and collective rights. ${ }^{161}$ Good governance referred in essence to 'a government's capability to manage a country's economic, political and social affairs' on the basis of the rule of law. Transparency, accountability and efficiency became key elements of good governance. ${ }^{162}$ Human rights were thus inherently linked to democracy and

155 Sano, ibid.; Eide, ibid.

156 Committee on Economic, Social and Cultural Rights, International technical assistance measures (Art. 22) CESCR General comment 2, (02/02/1990), $<$ http://tbinternet.ohchr.org/_layouts/treatybodyexternal/TBSearch.aspx?Lang=en \&TreatyID=9\&DocTypeID=11>, accessed 3 Mar 2016, para 7.

157 Ibid.

158 Cornwall and Nyamu-Musembi, Putting the 'Rights-Based Approach' to Development into Perspective, (2011), 1423.

159 Kirkemann Boesen and Sano, The Implications and Value Added of a Human Rights-Based Approach, (2010), 46-9.

160 Uvin, From the Right to Development to the Rights-Based Approach: How Human Rights Entered Development, (2007), 597-600; Sano, Development and Human Rights: The Necessary but Partial Integration of Human Rights and Development, (2010), 740.

161 Sano, ibid., 736.

162 Hamm, A Human Rights Approach to Development, (2001), 1020. 
good governance and gained significant importance as global values. ${ }^{163}$ Also the shift from sector- or project-based interventions to direct budget support was conducive to strengthening the human rights-based approach. Donor governments developed a vital interest in ensuring that their means were spent accordingly and engaged in strengthening public institutions and capacity-building of civil society to hold public actors accountable. ${ }^{164}$

In 1997, a wide-ranging UN Reform Program laid the foundation for mainstreaming human rights as core values in the work of all UN agencies. ${ }^{165}$ The new paradigm was prominently emphasised by Amartya Sen in UNDP's 2000 Human Development Report in which he stated that:

If human development focuses on the enhancement of the capabilities and freedoms that the members of a community enjoy, human rights represent the claims that individuals have on the conduct of individual and collective agents and on the design of social arrangements to facilitate or secure these capabilities and freedoms. ${ }^{166}$

Today the human rights-based approach has gained largely more practical relevance for donors and international NGOs than the abstract discussions on the right to development. ${ }^{167}$

The human rights-based approach is characterised by the shift from charity to rights. It departs from the idea of individuals as rights holders

163 Sano, Development and Human Rights: The Necessary but Partial Integration of Human Rights and Development, (2010), 736.

164 John Gaventa, Anne Marie Goetz et al., Bringing Citizen Voice and Client Focus into Service Delivery, (30.07.2001) <http://siteresources.worldbank.org/ INTPCENG/1143372-1116506145151/20511053/wp.pdf>, accessed 18 Nov 2016; Cornwall and Nyamu-Musembi, Putting the 'Rights-Based Approach' to Development into Perspective, (2004), 1424.

165 Urban Jonnson, Human Rights Approach to Development Programming, (2003), 10; United Nations, Renewing the United Nations, A/RES/52/12, (01.01.1997) <http://www.un.org/ga/documents/gares52/res5212.htm> accessed 03 Nov. 2016; Cornwall and Nyamu-Musembi, Why Rights Why Now? Reflections on the Rise of Rights in International Development Discourse, (2005), 1425.

166 United Nations Development Programme, Development Report: Human Rights and Development, (01.01.2000), <http://hdr.undp.org/en/content/humandevelopment-report-2000>, accessed 16 Jul 2018, 20.

167 Alston, Ships Passing in the Night: The Current State of the Human Rights and Development Debate seen through the Lens of the Millennium Development Goals, (2005), 798, 799. 
which are endowed with inherent human rights claims against state and non-state duty bearers that become accountable for their actions and omissions. It aims at tackling the underlying causes of marginalisation and achieving a positive transformation of power relations through legal empowerment. ${ }^{168}$ The human rights-based approach to development constitutes 'a fundamental value change, when compared to other notions of development, in particular those which use growth through market expansion as a dominant criteria'. ${ }^{169}$ The UN Common Understanding on a Human Rights-Based Approach to Development Cooperation states that:

1. All programmes of development co-operation, policies and technical assistance should further the realisation of human rights as laid down in the Universal Declaration of Human Rights and other international human rights instruments.

2. Human rights standards contained in, and principles derived from, the Universal Declaration of Human Rights and other international human rights instruments guide all development cooperation and programming in all sectors and in all phases of the programming process.

3. Development cooperation contributes to the development of the capacities of 'duty bearers' to meet their obligations and/or of 'rights-holders' to claim their rights. ${ }^{170}$ The notion of 'duty bearers' encompasses state and non-state actors. ${ }^{171}$

Elaborated in the development context, the human rights-based approach has subsequently been translated into various fields including the business context. ${ }^{172}$ Generally, it is characterised by four constituent elements which are closely interrelated: ${ }^{173}$

168 Jonnson, Human Rights Approach to Development Programming, (2003), 20-25; Cornwall and Nyamu-Musembi, Putting the 'Rights-Based Approach' to Development into Perspective, (2004), 1432.

169 Eide, Human Rights-Based development in the Age of Globalization, (2010), 295.

170 United Nations Development Group, The Human Rights Based Approach to Development Cooperation: Towards a Common Understanding Among UN Agencies, (01.01.2003), para 1.

171 Ibid., para 3.

172 United Nations, UN Practitioners' Portal on Human Rights Based Approaches to Programming (HRBA Portal), <http://hrbaportal.org/>, accessed 12 Nov 2016.

173 Kirkemann Boesen and Sano, The Implications and Value Added of a Human Rights-Based Approach, (2010), 58; United Nations Development 
1. The universality, inalienability, indivisibility, interdependence and interrelatedness of human rights: the universality of human rights requires treating all individuals, not only citizens, as equal rights holders. ${ }^{174}$ Human rights constitute inalienable and inherent rights that exist just by virtue of being human. ${ }^{175}$ They cannot be arbitrarily abolished and any interference needs to be proportional and based on legal grounds. All human rights are interdependent and inter-related so that the realisation of one right may impact or require the realisation of other rights. They are conceived as an indivisible framework, where all rights enjoy equal status and no one right shall prevail over the other. ${ }^{176}$ In practice, the human rights-based approach requires a holistic approach which aims for a progressive realisation of all human rights but allows at the same time for a necessary prioritisation. ${ }^{177}$

2. Non-discrimination and equality: the principles of nondiscrimination and equality have to be respected with regard to all outcomes and processes. All individuals are equal before the law and entitled to protection against discrimination of any kind such as race, colour, sex, language, political or other opinions, national or social origin, property, birth or other status. ${ }^{178}$ Discrimination

Group, The Human Rights Based Approach to Development Cooperation: Towards a Common Understanding Among UN Agencies, (01.01.2003), para 2.

174 United Nations General Assembly, Vienna Declaration and Program of Action A/CONF.157/23, (01.01.1993), para 5; Mac Darrow and Tomas Amparo, Power Capture and Conflict: A Call for Human Rights Accountability in Development Cooperation, Human Rights Quarterly 27/2 (2005), 501-2; Kirkemann Boesen and Sano, The Implications and Value Added of a Human Rights-Based Approach, (2010), 59.

175 United Nations General Assembly, Universal Declaration of Human Rights (UDHR), (01/01/1948), art 1.

176 United Nations General Assembly, Vienna Declaration and Program of Action A/CONF.157/23, (01.01.1993), para 5.

177 Darrow and Amparo, Power Capture and Conflict: A Call for Human Rights Accountability in Development Cooperation, (2005) 504-5; Kirkemann Boesen and Sano, The Implications and Value Added of a Human Rights-Based Approach, (2010), 60-1.

178 United Nations, International Covenant on Economic Social and Cultural Rights (ICESCR), (1966), art 2.2, art 3; United Nations, International Covenant on Civil and Political Rights (ICCPR), (1966), <https://www.ohchr.org/en/

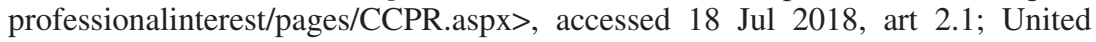
Nations General Assembly, Convention on the Rights of the Child (CRC), (1989), $<$ http://www.un.org/documents/ga/res/44/a44r025.htm>, accessed 16 Jul 2018, art 2 . 
encompasses both direct and indirect discrimination which may result from intended or non-intended effects of laws, policies, social, cultural or institutional practices. The human rights-based approach requires the assessment of structural discrimination patterns on a case by case basis and to address the root causes of discrimination. It might equally require special measures or affirmative actions. ${ }^{179}$

3. Participation and inclusion: the principles of participation and inclusion constitute both human rights objectives and procedural paradigms. ${ }^{180}$ They are inherently linked to the principles of non-discrimination and accountability. The right to participate guarantees, for example, everyone's right to take part in the government, to have equal access to public services, to take part in public elections, ${ }^{181}$ in his/her development as well as in the fair distribution of benefits. ${ }^{182}$

On the procedural level, the implementation of the right to participation is guided by a partnership approach. It goes beyond ad-hoc stakeholder contacts and is based on active citizenship which requires the capacity to analyse unequal relations at all levels. ${ }^{183}$ Effective participation is characterised by a genuine capacity to influence the economic and political agendas' ${ }^{184}$ It is strongly inter-related with other human rights such as freedom of expression, association or conscience as well as the realisation of basic economic, social and cultural rights. ${ }^{185}$

179 Darrow and Amparo, Power Capture and Conflict: A Call for Human Rights Accountability in Development Cooperation, (2005), 505-6; Kirkemann Boesen and Sano, The Implications and Value Added of a Human Rights-Based Approach, (2010), 63.

180 Jonnson, Human Rights Approach to Development Programming, (2003), $20-5$.

181 United Nations General Assembly, Universal Declaration of Human Rights (UDHR), (1948), art 21; United Nations, International Covenant on Civil and Political Rights (ICCPR), (1966), art 25.

182 United Nations General Assembly, Declaration on the Right to Development, (1986), art 2.

183 Vene Klasen et al., Rights-based Approaches and Beyond: Challenges of Linking Rights and Participation A joint initiative of the Participation Group at IDS and Just Associates, (14.12.2004), <http://www.ids.ac.uk/files/Wp235.pdf>, accessed 8 Nov 2016, 5.

184 Darrow and Amparo, Power Capture and Conflict: A Call for Human Rights Accountability in Development Cooperation, (2005), 507.

185 Ibid., 509. 
4. Accountability and rule of law: the principle of accountability constitutes the most typical characteristic that distinguishes the human rights-based approach from other development approaches such as the basic needs approach. It recognises individuals as rights-holders that are able to hold duty bearers to account for their non-compliance with their international human rights obligations. A particular feature of the human rights-based approach is that it aims to take into account the duties of all relevant actors, including individuals, states, local organisations and authorities, private companies, donors and international institutions. Human rights accountability refers not only to the outcomes but equally to the process. ${ }^{186}$ Duty bearers have to establish accountability mechanisms which allow for redress. The realisation of accountability also requires paying due attention to access to information, processes and institutions. ${ }^{187}$

The principle of rule of law means that all actors in a given state, as well as the state itself, are accountable to the law. The government is embedded in a legal framework and accepts that the law will be applied to its own conduct. The central institutions of the legal system, such as courts, prosecutors and the police are competent, fair, impartial and independent of political influence. ${ }^{188}$ The rule of law provides the basis for a democratic order that should prevent an arbitrary exercise of power and impunity. ${ }^{189}$

The development community has frequently been criticised for applying the principle of rule of law as a panacea to support transition countries on their way to economic stability, democracy, justice and the realisation of human rights. ${ }^{190}$ Rule of law has certainly had a positive impact on good

186 Kirkemann Boesen and Sano, The Implications and Value Added of a Human Rights-Based Approach, (2010), 61-2; Darrow and Amparo, Power Capture and Conflict: A Call for Human Rights Accountability in Development Cooperation, (2005), 511.

187 Kirkemann Boesen and Sano, ibid., 62.

188 Thomas Carothers, Promoting the Rule of Law Abroad: In Search of Knowledge, (Washington, DC: Carnegie Endowment for International Peace 2006), 4.

189 Institute for Democracy and Electoral Assistance and International Development Law Organization, Linkages between the rule of law democracy and sustainable development (2012) < http://www.idea.int/un/upload/Concept-NoteIDEA-IDLO-Italy-rev-5-0-Final.pdf>, accessed 13 Jul 2016, 2, 3.

190 Rachel Kleinfeld, Competing Definitions of the Rule of Law, in Thomas Carothers (ed.), Promoting the Rule of Law Abroad. In Search of Knowledge 
governance and poverty alleviation. Yet, its narrow legal focus and its top-down approach have often ignored local power structures and domestic processes of change. ${ }^{191}$ This has become specifically problematic as rule of law has sometimes tended to become a substitute for human rights-based accountability. ${ }^{192}$ Golub for example identified the following differences between legal empowerment and rule of law. In cases of empowerment:

(1) attorneys support the poor as partners, instead of dominating them as proprietors of expertise; (2) the disadvantaged play a role in setting priorities, rather than government officials and donor personnel dictating the agenda; (3) addressing these priorities frequently involves non-judicial strategies that transcend narrow notions of legal systems, justice sectors, and institution building; and (4) even more broadly the use of law is often just part of integrated strategies that include other development activities. ${ }^{193}$

Rule of law may therefore constitute only an element of legal empowerment but not a substitute. ${ }^{194}$

Applying a human rights-based approach means that individuals are recognised as key actors taking part in their own development, rather than passive recipients of commodities and services. Development strategies are empowering and focus on marginalised groups. ${ }^{195}$ They are based on an analysis of the human rights obligations of duty bearers, claims of rights holders and on the identification of the underlying root causes of the non-realisation of rights. Programmes aim to enhance the capacities of rights holders and duty bearers and are informed by the recommendations of human rights bodies. Development processes are locally owned by the countries where they are implemented. Bottom-up and top-down approaches are combined. Outcomes and processes are monitored and evaluated on the basis of measurable targets guided by

(2006), 31; Carothers, Promoting the Rule of Law Abroad: In Search of Knowledge, 3-5.

191 Carothers, Promoting the Rule of Law Abroad. In Search of Knowledge, 11; Stephen Golub, The Legal Empowerment Alternative, in Thomas Carothers (ed.), Promoting the Rule of Law Abroad. In Search of Knowledge (2006), 161-3, 178.

192 Darrow and Amparo, Power Capture and Conflict: A Call for Human Rights Accountability in Development Cooperation, (2005), 511.

193 Golub, The Legal Empowerment Alternative, (2006), 161-2.

194 Ibid., 163.

195 United Nations Development Group, The Human Rights Based Approach to Development Cooperation: Towards a Common Understanding Among UN Agencies, (2003), para 1. 
human rights standards. ${ }^{196}$ Programmes ultimately support accountability of all duty bearers to all stakeholders. ${ }^{197}$ To date the human rights-based approach constitutes a key method in integrating human rights in development cooperation - even if it is still far from being mainstreamed on the ground.

The human rights-based approach has also been criticised for some substantial issues. One concern was for example, its traditional nation state focus which relies again primarily on domestic accountability while obligations of the international community or non-state actors still seem rather vague and remain largely off the table. ${ }^{198}$ It has therefore been considered to feed again into the interests of industrialised states which have traditionally opposed extraterritorial state obligations. ${ }^{199}$ Critical scholars equally noted that it fails to address the complexities of global decision-making and power relations which actually impact the domestic capacities of developing states. ${ }^{200}$ The human rights-based approach has equally been considered as a 'rhetorical repackaging' to affirm the status quo of existing power relations. The development community was criticised for benefiting from the moral authority of the legal language and for using it as 'a fig leaf' to justify the existing practice by arguing that 'development projects by definition constitute an implementation of human rights' ${ }^{201}$

Another concern was the potential of double standards. Uvin underlined that: "if the development community is serious about human rights, then the rights focus cannot be limited to projects'. ${ }^{202} \mathrm{He}$ emphasised that:

if donors, be they governments, NGOs, or international organisations, profess attachment to human rights in their development aims, they must be willing to apply the rights agenda to all of their own actions (the inward focus), and to

196 Ibid., para 3.

197 Ibid., para 1.

198 Ibhawoh, The Right to Development: The Politics and Polemics of Power and Resistance, Human Rights Quarterly, (2011), 76-104, 99.

199 Ibid., 100.

200 Alston, Ships Passing in the Night: The Current State of the Human Rights and Development Debate seen through the Lens of the Millennium Development Goals, (2005), 802; Ibhawoh, ibid.; Uvin, From the Right to Development to the Rights-Based Approach: How Human Rights Entered Development, 601.

201 Uvin, Human Rights and Development, (2004), 53.

202 Uvin, From the Right to Development to the Rights-Based Approach: How Human Rights Entered Development, 604. 
the global political economy of inequality within which they occupy such privileged places (the outward focus). In the absence of such moves, the human-rights focus is little more than a projection of power, and the world has had enough of that already. In other words, the promotion of human rights begins with oneself. ${ }^{203}$

From a broader perspective the whole concept of human rights has also been questioned for its efficiency and impact. The strict legal focus has been found to ignore 'a wide range of strategies, tactics and institutions through which people may frame and make rights claims outside the formal legal instruments and institutions'. ${ }^{204}$ It was argued that particularly marginalised groups' access to legal institutions may be impeded by a broad range of factors including cost and time constraints, the lack of trust in the formal system as well as fear of social reprisals at community level. ${ }^{205}$

Development practitioners also raised criticisms. Some of them argued that the human rights-based approach was still too abstract and failed to offer adequate guidance for solving practical challenges on the ground. ${ }^{206}$ One of the major dilemmas that has been identified is the necessity to treat all human rights as equal, indivisible and interrelated. This frequently conflicted with the operational need to set priorities and to accept trade-offs. ${ }^{207}$ Sometimes development workers preferred 'to use an alternative analytical framework that better reflects their specific concerns and is capable of being sensitised to at least certain human rights issues but would not pass muster as a human rights-based approach' ${ }^{208}$ Moreover, the human rights tendency to condition development assistance has often been found to "weaken the quality of governance, the

203 Ibid.

204 Cornwall and Nyamu-Musembi, Putting the 'Rights-Based Approach' to Development into Perspective, (2004), 1418.

205 Celestine Nyamu-Musembi, Towards an Actor-oriented Perspective on Human Rights, IDS Working paper 169, (01.10.2002), <http://www.ids.ac.uk/ files/Wp169.pdf>, accessed 19 Nov 2016, 10.

206 Alston, Ships Passing in the Night: The Current State of the Human Rights and Development Debate seen through the Lens of the Millennium Development Goals, (2005), 802-3.

207 Alston, ibid., 807; Elvira Domínguez Redondo, The Millennium Development Goals and the human rights based approach: Reflecting on structural chasms with the United Nations system, The International Journal of Human Rights 13/1 (2009), 37.

208 Alston, ibid., 806, 807. 
domestic accountability of governments, the legitimacy of opposition groups, and the capacity to develop internal processes of change'.209

A range of suggestions were made to address these concerns and to strengthen the human rights-based approach. Scholars have repeatedly called for more elaboration on international accountabilities and for adequately extending accountability to other relevant actors, including individuals, local organisations, donors and private corporations. ${ }^{210}$ It was equally suggested that multilateral and bilateral development activities should be monitored by UN human rights mechanisms. ${ }^{211}$ With regard to the paradigm of the indivisibility of human rights Alston noted that if every possible human rights element is deemed to be essential or necessary, then nothing will be treated as though it is truly important; a list of requirements that is too demanding is unlikely to be taken seriously by practitioners who are operating under major time and resource constraints'. ${ }^{212}$ He called for a more realistic view of development workers' scepticism to the human rights-based approach and suggested that it would be beneficial to demonstrate its feasibility and practicability in different circumstances. ${ }^{213}$

Over the last decade, the international discussions have shown that human rights have become an indispensable component for sustainable development. The Millennium Development Goals (MDGs) which were conceived as measurable development targets with regard to poverty, universal primary education, gender equality, health, environmental sustainability and international cooperation marked an important step towards enhanced convergence. ${ }^{214}$ The MDGs however did not, fully live up to human rights requirements. Concerns were raised in regards to fostering technical and financial solutions instead of contributing to a transformation of power relations, the disregard of poverty in developed and middle-income countries or the lack of accountability mechanisms

209 Uvin, Human Rights and Development, (2004), 77.

210 Kirkemann Boesen and Sano, The Implications and Value Added of a Human Rights-Based Approach, (2010), 61; UNDP, Human Development Report 2000: Human Rights and Human Development, (2000), 13.

211 Hamm, A Human Rights Approach to Development, (2001), 1031.

212 Alston, Ships Passing in the Night: The Current State of the Human Rights and Development Debate seen through the Lens of the Millennium Development Goals, (2005), 807.

213 Ibid., 807-8.

214 OHCHR, Claiming the Millennium Development Goals: A Human Rights Approach, (28.05.2008), <http://www.ohchr.org/Documents/Publications/Claiming _MDGs_en.pdf>, accessed 16 Sep 2016, vii; United Nations, United Nations Millennium Declaration A/RES/55/2, (18.09.2000). 
ensuring that rich countries live up to their commitments. ${ }^{215}$ In 2008, the Office of the High Commissioner of Human Rights (OHCHR) therefore proposed a 'Human Rights Approach to the MDGs' which aimed to better align the MDGs with human rights to be transformative and not technocratic and to ensure enforceable rights to claim the MDGs. ${ }^{216}$ Even before 2015 it became clear that the MDGs could not be attained.

The international community has therefore engaged in discussions on the Post-2015 Development Agenda which has been characterised by a stronger demand to integrate human rights. ${ }^{217}$ The Outcome Document of the Rio +20 Conference calls for a human-rights based policy coherence in all development related areas, including economic policies. It draws on key elements of a human rights-based approach, in particular, nondiscrimination, empowerment, participation, inclusion, people-centred development and accountability. 218

In 2013, the High Commissioner for Human Rights issued ten key recommendations on how to integrate human rights into the new development agenda. Accordingly the 'Post-2015 Agenda must build on a human rights-based approach, in both process and substance' and development efforts must be directed towards the realisation of human rights. The High Commissioner underlined that development progress can no longer be measured by narrow socio-economic indicators as suggested by the MDGs but must include the realisation of economic, social and cultural rights as well as civil and political rights. It must be underpinned by equality, equity and non-discrimination and strive towards ending poverty, empowering marginalised groups and advancing a healthy environment. ${ }^{219}$

215 Malcom Langford, Fons Coomans and Felipe Gomez Isa, Extraterritorial Duties in International Law, in Malcom Langford, Wouter Vandenhole, Martin Scheinin et al. (eds), Global Justice, States Duties: The Extraterritorial Scope of Economic, Social and Cultural Rights in International Law (New York: Cambridge University Press, 2013) 85, 86; OHCHR, Claiming the Millennium Development Goals: A Human Rights Approach, (28.05.2008), 4, 5; Langford, Coomans and Gomez Isa, Extraterritorial Duties in International Law, 83.

216 OHCHR, ibid., vii.

217 United Nations, Human Rights and Post-2015 Development Agenda, $<$ http://www.ohchr.org/EN/Issues/MDG/Pages/Intro.aspx>, accessed 12 Nov 2017.

218 United Nations, The Future We Want: Outcome Document Rio+20 United Nations Conference on Sustainable Development, (2012), 1.

219 OHCHR, Open Letter: Human Rights in the Post-2015 Agenda, (06.06.2013), <http://www.ohchr.org/Documents/Issues/MDGs/OpenLetterMS_ Post2015.pdf>, accessed 12 Nov 2017. 
In September 2015, the United Nations General Assembly adopted the 2030 Agenda for Sustainable Development, along with a set of 17 Sustainable Development Goals (SDGs) and 169 associated targets. They have widely incorporated these recommendations. The SDGs apply to all countries of the world, they no longer only apply to developing countries and are conceived as universal and indivisible goals for all countries. ${ }^{220}$ They underline the important role of the business sector which should use its innovation and creativity in view of achieving sustainable development through core business activities. ${ }^{221}$

In contrast to the previous MDGs, the SDGs have been developed over a period of three years in close cooperation with a broad range of stakeholders, which included governments, civil society organisations and the business sector. ${ }^{222}$ The UN resolution clearly states that '[...] it is we the peoples who are embarking today on the road to 2030. Our journey will involve Governments as well as parliaments, the United Nations system and other international institutions, local authorities, indigenous peoples, civil society, business and the private sector, the scientific and academic community - and all people [...]'.223

The Agenda 2030 is intrinsically based on human rights. It underlines that the SDGs 'seek to realize the human rights of all and to achieve gender equality and the empowerment of all women and girls'.224 It refers to the Universal Declaration of Human Rights and international human rights treaties and emphasises that the SDGs should be implemented in line with states' international human rights obligations. ${ }^{225}$

220 OHCHR, Transforming Our World: Human Rights in the 2030 Agenda for Sustainable Development, A/RES/70/1, (21/10/2015).

221 United Nations, Transforming our world: the 2030 Agenda for Sustainable Development A/RES/70/1, (21/10/2015), para 67, 68; UN Global Compact, The SDG Compass Helps Companies Take Action on New UN Goals, (2015) $<$ https://www.unglobalcompact.org/news/2551-09-26-2015>, accessed 13 Jul 2016.

222 Corporate Citizenship, From My World to Our World: What the Sustainable Development Goals Mean for Business, (2015) <http://corporatecitizenship.com/wp-content/plugins/email-before-download/download.php?dl=76 55c5c1284d3471699694de68a867a8>, accessed 13 Jul 2016, 1-2.

223 United Nations, Transforming our world: the 2030 Agenda for Sustainable Development A/RES/70/1, (21/10/2015), para 52.

224 Ibid., preamble.

225 Ibid., paras 10, 18. 
The OHCHR noted that: 'The SDGs offer a new, more balanced paradigm for more sustainable and equitable development.' 226 It highlighted that the 17 SDGs effectively reflect the human rights framework (economic, social and cultural as well as civil and political rights) and are thus much broader than the MDGs which focused only on a 'narrow set of economic and social issues'.227 Most of the goals require international cooperation of all actors and are influenced by underlying human rights standards. Goal 3 requires for example 'to achieve universal health coverage, including financial risk protection, access to quality essential health-care services and access to safe, effective, quality and affordable essential medicines and vaccines for all' ${ }^{228}$

The new Agenda has an overarching focus on combatting discrimination and inequalities. According to the OHCHR it "includes perhaps the most expansive list of groups to be given special focus of any international document of this kind'.229 Those comprise children, youth, women and girls, elderly people, people with disabilities and HIV/AIDS, refugees and migrants, internally displaced people and indigenous people. 230

One of the most progressive steps is that the Agenda 2030 requires the creation of a human rights-sensitive SDG indicator framework to monitor progress as well as the establishment of an effective accountability framework at national, regional and global levels. The latter should equally include the activities of non-state actors. The UN Guiding Principles on Business and Human Rights are explicitly mentioned and suggested as accountability framework for the private sector. A High Level Political Forum should regularly review the implementation of the Agenda including the SDGs. ${ }^{231}$

226 Office of the United Nations High Commissioner for Human Rights, Transforming Our World: Human Rights in the 2030 Agenda for Sustainable Development, 1.

227 Ibid.

228 United Nations, Transforming our world: the 2030 Agenda for Sustainable Development A/RES/70/1, (21/10/2015), Goal 3.

229 Office of the United Nations High Commissioner for Human Rights, Transforming Our World: Human Rights in the 2030 Agenda for Sustainable Development 2.

230 United Nations, Transforming our world: the 2030 Agenda for Sustainable Development A/RES/70/1, (21/10/2015), para 23.

231 Office of the United Nations High Commissioner for Human Rights, Transforming Our World: Human Rights in the 2030 Agenda for Sustainable Development, 2. 
Despite these positive developments the OHCHR also identified some gaps. The most evident one is that the Goals are not formulated in human rights language although they cover to a large extent their content. Furthermore, some targets are limited by requiring only compliance with national law which may not live up to international standards (targets 5.6, 5.a, 16.10, 16.2). A few targets may have unintended effects (e.g., 6.2. which aims at eliminating open defecation and may implicitly hit the poorest of the poor). The OHCHR emphasises that in these cases it will be critical to ensure a human rights compliant implementation of the SDGs. ${ }^{232}$

In conclusion it seems that we are witnessing a very promising development in the stony path of convergence between development cooperation and human rights. The Agenda 2030 and the SDGs have not only clearly acknowledged that sustainable development is intrinsically linked to human rights but propose equally concrete steps for their implementation. They call upon all countries, non-state actors and international organisations in the world to jointly achieve commonly agreed targets. Thereby they take a promising path towards a much more comprehensive, inclusive and human rights-based approach on development which will hopefully lead to more accountability in the future.

232 Ibid., 1-2. 